\title{
A ,Kapos-vonal” középsố szakaszának szerkezeti-mélyföldtani viszonyai és neotektonikai jellegei a legújabb geofizikai vizsgálatok tükrében
}

\author{
†HoRváth Ferenc ${ }^{1}$, KoroKnai Balázs ${ }^{1}$, Tóth Tamás ${ }^{1}$, Wórum Géza ${ }^{1}$, KonRÁd Gyula $^{2}$, Kádi Zoltán ${ }^{1}$, Kudó István ${ }^{3}$, HámORI

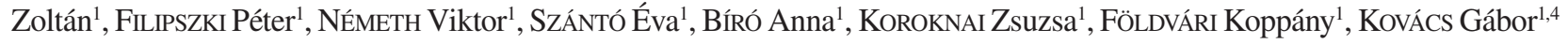 \\ ${ }^{1}$ Geomega Kft., 1095 Budapest Mester u. 4 \\ ${ }^{2}$ Geológus Kft. \\ ${ }^{3}$ Robert Bosch Kft., 1103 Budapest Gyömrői u. 104 \\ ${ }^{4}$ ELTE BDPK Földrajzi Tanszék, 9700 Szombathely Károlyi Gáspár tér 4.
}

\section{Structural-geological and neotectonic features of the middle portion of the Kapos line based on the results of latest geophysical research}

Abstract

The present study summarizes the results of the most recent geophysical research on the middle portion of the Kaposline (central Hungary). This work is dedicated to the memory of our unforgottable Colleague, Friend and Master, late Prof. Dr. Ferenc Horváth.

As a first step a complex geophysical-geological database was formed integrating all available previous and newly measured 2D/3D reflection seismic, as well as borehole data, including also the results of new stratigraphic wells. A new, geologically and geometrically consistent 3D geological model of the study area was built by the interpretation of this integrated database. This 3D model consists of five geological horizons of basic importance within the study area (top pre-Cenozoic basement, top clastic/volcanic Lower Miocene, top marine Middle Miocene, top Endrőd and top Algyố Formations), as well as the interpreted faults. Considering the obtained new results, the previously published geologicalstructural models were critically re-evaluated and — if necessary — modified.

One of the most important geological results of the research is the reambulation of the spatial extent, structural and facies relationships of the crystalline and Mesozoic basement rocks in the study area based on integrated evaluation of seismic and well data. Furthermore, the demonstration of the pronounced Early Miocene rifting event associated with the formations of several smaller basins with a depth up to 2 kilometers also represents a fundamental result. These basins were filled by a large amount of continental clastic sediments and coeval calc-alkaline volcanics. These findings underline the importance of the previously less known (and emphasized) role of the Early Miocene phase during the formation of the Pannonian basin.

Based on the results of fault mapping the most important fault zones of the study area involve the ENE-WSW striking „Kapos line”, furthermore the NE-SW striking Dunaszentgyörgy-Harta, and the Bonyhád fault zones, the latter mapped first during this research. All of these fault zones are characterized by steep dip $\left(\geq 60-70^{\circ}\right)$. The Bonyhád fault zone in the southwest joins to northern imbricate zone of the Mecsek Mts. The general fault pattern of the study area is characterised mostly by NE-SW striking faults being (sub)parallel to the mentioned major fault zones. Structurally less important, NW-SE striking faults occur mostly south of the „Kapos line”.

The results of detailed fault mapping clarified that a single, along strike structurally and geometrically uniform „Kapos line” does not exist in the study area. Instead, this fault zone can be divided into a western (,Kapos-W”) and an eastern segment (,Kapos-E”), which differ both in dip direction and — in accordance with previous literature data observed neotectonic activity. The eastern „Kapos line”, the Dunaszentgyörgy-Harta and the Bonyhád fault zones all show pronounced neotectonic activity. Moreover, they form the most important elements of a regional-scale, broad, neotectonic sinistral strike-slip shear zone consisting of predominantly NE-SW and ENE-WSW striking individual faults. The strike-slip kinematics of this shear zone is clearly indicated by the observed internal ,flower structure" of the individual fault zones, as well as by the associated secondary fault pattern (Riedel faults).

The location of the high-resolution 2D and pseudo-3D shallow geophysical surveys were determined based on the results of the introduced 3D geological-structural model of the study area. The results of these high-resolution geophysical surveys and the subsequent trenching and shallow boreholes clearly proved the Quaternary activity of the Dunaszentgyörgy-Harta fault zone. Moreover, the trenching indicated the Late Quaternary activity of this fault zone, since the tectonic deformation of the exposed Upper Pleistocene blown sand was observed and documented in the trench. Quaternary tectonic activity was also supported by numerous other previous and the present research-related observations, although they are not discussed in details in this study. The introduced results are also in accordance with literature data published on the tectonics of the eastern „Kapos-line” (Danube-Tisza interfluve and east of the river Tisza).

The results presented in this study are related to the geological research program (FKP) of the Paks II project executed during 2015-2016.

Keywords: Kapos line, seismic interpretation, high-resolution shallow geophysical surveys, structural-geological 3D model, Dunaszentgyörgy-Harta and Bonyhád fault zones, neotectonics, central Hungary 
Összefoglalás

Tanulmányunkban a Kapos-vonal középsố szakaszának legújabb geofizikai vizsgálatainak eredményeit tekintjük át. Munkánkkal tavaly ősszel elhunyt Kollégánk, Barátunk, Tanárunk és Mesterünk — Prof. Dr. Horváth Ferenc — emléke előtt tisztelgünk.

A kutatási területen elérhetô korábbi és újonnan mért 2D/3D reflexiós szeizmikus és fúrási adatok integrációjával komplex adatbázist alakítottunk ki, amelynek értelmezésével földtanilag és geometriailag egyaránt konzisztens, új 3D földtani-tektonikai modellt hoztunk létre. A modell a vizsgált terület földtani felépítésének alapvonásait szem előtt tartva öt meghatározó jelentőségú földtani horizont (prekainozoos aljzat-tető, alsó-miocén tető, középső-miocén tető, Endrődtető, Algyő-tetô) és az értelmezett vetők téradatrendszerét tartalmazza. A kialakított 3D modell alapján elvégeztük a korábbi vizsgálatokkal nyert földtani-szerkezeti kép felülvizsgálatát, és azt szükség szerint módosítottuk, illetve pontosítottuk/kiegészítettük.

A kutatás mélyföldtani szempontból legfontosabb eredményei közé tartozik a kristályos és mezozoos aljzatképződmények szerkezeti, elterjedési és kifejlődési viszonyainak reambulációja a lemélyült új szerkezetkutató fúrások és a szeizmikus adatrendszer integrált értelmezése alapján. Ugyancsak alapvető jelentőségú a markáns kora-miocén riftesedés kimutatása, amely során intenzív, többfázisú mészalkáli vulkáni múködés, illetve egyidejú kontinentális üledékképződés zajlott a létrejött, helyenként akár 2 km mélységú süllyedékekben. Mindez tágabb kontextusban a Pannon-medence korábban kevésbé ismert (és hangsúlyozott) kora-miocén kialakulási szakaszának jelentőségére hívja fel a figyelmet.

A vetőtérképezés eredményei alapján a szúkebb kutatási terület meghatározó vetôzónái a KÉK-NyDNy-i csapású „Kapos-vonal”, továbbá az ÉK-DNy-i csapású Dunaszentgyörgy-Harta és az ezen kutatás során először térképezett Bonyhádi vetőzóna, amelyeket mind meredek dőlés $\left(\geq 60-70^{\circ}\right)$ jellemez. A Bonyhádi vetőzóna délnyugati irányban a Mecsek északi pikkelyzónájához csatlakozik. A terület szerkezeti képét összességében a fentiekkel többnyire (közel) párhuzamos törések uralják, míg az előbbiekre kb. merôleges ÉÉNy-DDK-i csapású, szerkezetileg kevésbé jelentős törések főként a Kapos-vonaltól délre jelentkeznek.

Eredményeink alapján geometriai-szerkezeti értelemben egységes Kapos-vonal nem létezik: e vetôzóna a kutatási területen ugyanis egy nyugati (,Kapos-Ny”) és egy keleti szegmensre (,Kapos-K”) bontható, amelyek mind dőlésirányban, mind az észlelt neotektonikus aktivitásban — összhangban a korábbi szakirodalmi adatokkal — markánsan különböznek. A vizsgált területen élénk neotektonikus aktivitást mutató Kapos-K, Dunaszentgyörgy-Harta és Bonyhádi vetőrendszerek regionális léptékben egy ÉK-DNy-i és KÉK-NyDNy-i csapású elemekből felépuilő, széles nyírási zónát körvonalaznak, amely a neotektonikus fázisban balos eltolódásként múködött. Ezt igazolja az egyes vetôzónákban megfigyelt tipikus „virágszerkezetet” mutató belsố struktúra, továbbá a kapcsolódó másodlagos formaelemek (Riedel-törések) is.

A kialakított 3D modell eredményeinek figyelembevételével telepített nagyfelbontású 2D és pszeudo-3D sekélygeofizikai vizsgálatok, valamint az ezek eredményei alapján kijelölt árkolás és sekélyfúrások adatai bizonyították a Dunaszentgyörgy-Harta vetôzóna negyedidőszaki, sôt az árkolás eredményei szerint késô-negyedidőszaki aktivitását, hiszen a kutatóárokban feltárt késő-pleisztocén végi futóhomok tektonikus eredetú deformációja jelentkezett. A fiatal negyedidôszaki tektonikai aktivitást a kutatási területen számos további korábbi, illetve a jelen kutatáshoz kapcsolódó, de e tanulmányban nem részletezett neotektonikai megfigyelés is alátámasztja. Mindezen eredmények a szakirodalomban a Kapos-vonal keleti szakaszáról (Duna-Tisza köze és Tiszántúl) közölt tektonikai adatokkal és értelmezéssel teljes összhangban állnak.

A tanulmányunkban ismertetett eredmények a Paks II földtani kutatási programjának (FKP) keretében 2015-2016 során elvégzett földtani-geofizikai kutatásokhoz kapcsolódnak.

Tárgyszavak: Kapos-vonal, szeizmikus értelmezés, nagyfelbontású sekély-geofizikai vizsgálatok, 3D földtani-tektonikai modell, Dunaszentgyörgy-Harta és Bonyhádi vetôzóna, neotektonika, Közép-Magyarország

\section{Bevezetés}

Hazánk egyik kiemelkedő jelentőségú szerkezeti eleme a „Kapos-vonal”, amelynek definíciója és részletes leírása NÉMEDI VARGA (1977) munkájához füződik. E tanulmányban a „vonal” definíciója fokozatosan bővülő területi és szakirodalmi kitekintéssel született meg: az elsődleges meghatározás fúrási észlelések alapján történt Dombóvár és Kurd közt mintegy 20 km hosszúságú szakaszon. A közvetlen adatok alapján definiált vonalat korábbi földtani, hidrogeológiai, szeizmológiai és a negyedkori kéregmozgásokra vonatkozó eredmények figyelembevételével (BALOGH et al. 1958; ERdÉlyI 1961, 1962; CSOMOR \& KISS 1962; RÓNAI 1973) először a Kapos-völgy teljes hosszára terjesztette ki NÉMEDi VARGA. Végül — messzemenóen támaszkodva a korábbi átfogó geofizikai és nagyszerkezeti elemzések eredményeire (SCHEFFER \& KÁNTÁs 1949, SCHEFFER 1960, KőRÖssy 1963, Posgay 1967) — NÉMEdi VARGA országos jelentőségú, Gyékényestől a „,szolnok-ebesi diszlokációs övig” (KőRÖSSY 1963) húzódó, elsőrendű szerkezeti övnek tekintette a „Kapos-vonalat” (lásd 1. ábra), amely „,a Pannon-medencének egyik fontosabb mezo-kainozoos mozgásfelületeként is felfogható...". A vonal Kaposfó és Pincehely közti szakaszán NÉMEDI VARGA (1977) szerint a „fiatal (pannóniai) orogén és epirogén mozgásokon kívül jelenkori mozgásokkal is számolni kell”.

A tudománytörténeti előzményeket tekintve kell megemlíteni, hogy a Dunától keletre már az ifj. Lóczy és SzENTES F. által készített, majd az ifj. LócZY által publikált szerkezeti térkép (LócZY 1939) is ábrázolt Paks és Szolnok közt vetôt, ugyanakkor Pakstól nyugatra térképükön a Kapos-vonal ma elfogadottnak tekintett lefutásától eltérô megoldás látható ( 1 . ábra). A Kapos-vonalhoz kapcsolódó újabb munkák közül feltétlenül ki kell emelni PoGÁCSÁs et al. (1989) eredményeit, aki szerzőtársaival az Alföldön olajipari szeizmikus szelvények felhasználásával jelölte ki a Paks-Kiskőrös-Szol- 


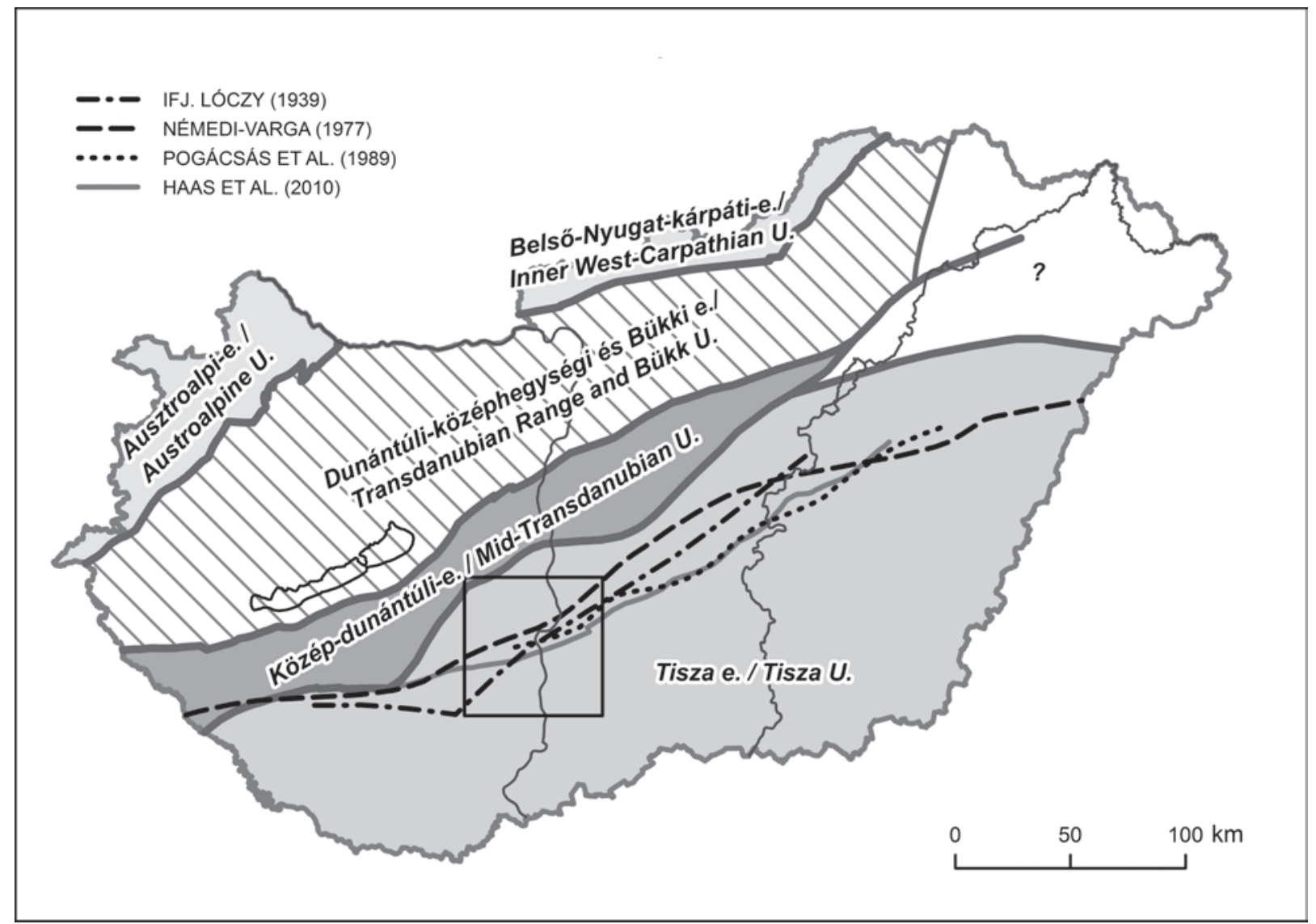

1. ábra. A „Kapos-vonal” (illetve egyes szegmenseinek) helyzete különböző szerzők szerint és a tárgyalt kutatási terület (fekete poligon) elhelyezkedése Magyarország egyszerűsített nagyszerkezeti térképén (HAAs et al. 2010 után)

Figure 1. The position of the „Kapos-line” (and its segments) according to different authors and the location of the study area (black polygon) shown on the simplified pre-Tertiary structural map of Hungary (after HAAS et al. 2010)

nok-Kisújszállás balos oldalelmozdulásos tektonikus övet, amely többé-kevésbé egybeesik a HAAs et al. (2010) aljzattérképén is ábrázolt Kapos-vonal (1. ábra) Dunától keletre esô szakaszával. Az elmozdulás horizontális mértékét a szerzők Kiskőrös térségében legalább 8 kilométerre becsülték. Ezen túlmenően PoGÁCSÁs et al. (1989), DETZKYNÉ LŐRINCZ (1996, 1997) és TóTH \& HoRVÁTH (1999) a szeizmikus és fúrási adatok integrált értelmezésével igazolták e tektonikus öv pannóniai-kvarter aktivitását is.

A közelítően KÉK-NyDNy-i csapású Kapos-vonal hazánk legújabb prekainozoos aljzattérképe (HAAs et al. 2010) szerint nyugaton a Tiszai- és a Közép-dunántúli nagyszerkezeti egységek határát alkotja. E területen a Kapos-vonal tehát elsőrendú szerkezeti elem, és az ún. Közép-magyarországi-vonal (SzEPESHÁzY 1975) nyugati részét képezi. Dombóvár térségében az ott közel K-Ny-i csapású Közép-magyarországi-vonal markáns irányváltással ÉK-i irányba fordul (ún. Tamási-vonal), míg a Kapos-vonal KÉK-NyDNy-i csapással innét a Tiszaiegységen belül, annak legészakabbi, ún. Mecseki-alegységében halad tovább. A szerkezeti zóna a Dunától keletre is hosszan nyomozható az Alföldön: a Tiszát Martfú közelében harántolja, majd keleten az alföldi flisövben végződik el (1. ábra).
Jelen munkában e kiemelkedő jelentőségú szerkezeti elem középsố szegmensének (1. ábra) legújabb geofizikai vizsgálati eredményeiről adunk áttekintést.

\section{A Kapos-vonal középsô szegmensének tektonikai képe a korábbi kutatási eredmények alapján}

A Kapos-vonal Dunát keresztező, középső szegmensét is magába foglaló terület vizsgálatát a paksi atomerómú tágabb környezete tektonikai viszonyainak részletes megismerése indokolta. E vizsgálatokra az 1980-as évektől került sor. Az 1990-es évek első felére a lezajlott célirányos szeizmikus és fúrásos kutatások alapján világossá vált, hogy ,... Paks alatt húzódik át DNy-ÉK-i irányban az ország medencealjzatának legnagyobb jelentőségú töréses öve ..." (BALlA et al. 1993). A vizsgálatok eredményeit összegző vetôtérképen (BALLA 1994; 2. ábra) a szerkezeti képet egy KÉK-NyDNy-i csapású, meghatározó jelentôségú tektonikai zóna (a Kapos-vonal: D) uralja, amelyből ÉK-i, illetve DNy-i irányba további kisebb vetőzónák (B-L) ágaznak ki. BALLA et al. (1997) munkája ugyanezt a szerkezeti képet közli néhány kisebb jelentőségú mellék- 


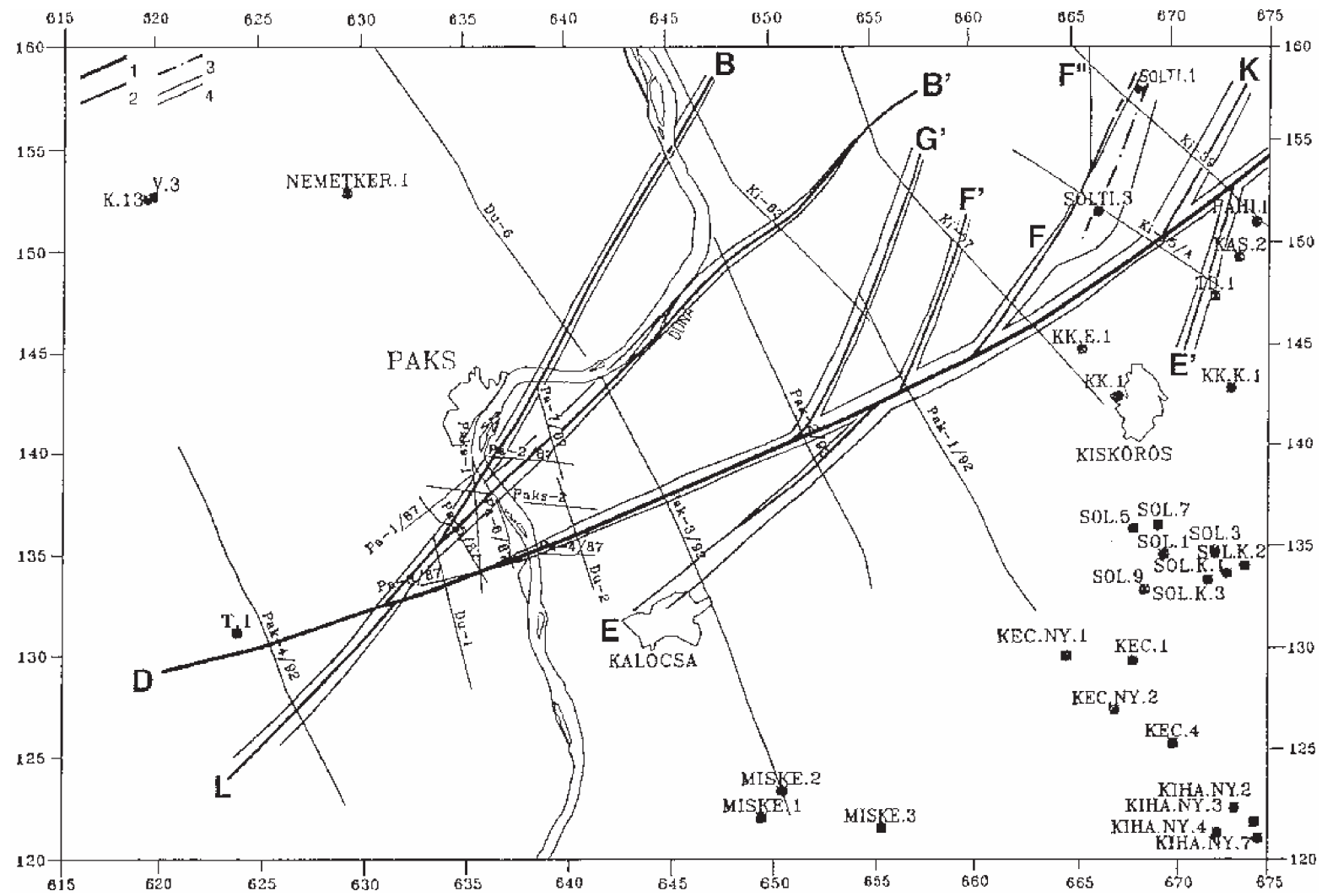

2. ábra. Vetőtérkép (BALLA 1994) a Paks környezetében mért 2D szeizmikus szelvények (vékony vonalak) és mélyfúrási adatok (fekete körök) értékelése alapján. A Kapos-vonalból (D) kiágazó mellékvetőket B-L betűk jelzik. A vetővonalakat két oldalról szegélyező vékonyabb vonalak a legfiatalabb aktivitású vetőzónákat („kiújulási öv”) mutatják. A B’ jelủ vető a legújabb kutatások során Dunaszentgyörgy-Harta vetőként (l. később) azonosított szerkezeti elemet jelzi

Figure 2. Fault map (BALLA 1994) of the Paks area based on the integrated evaluation of 2D seismic lines (thin lines) and well data (black dots). The Kaposline (D) and associated minor faults (B-L letters) are shown. Thin lines on both sides of the mapped faults indicate their young reactivation. The fault indicated by B' corresponds to the Dunaszentgyörgy-Harta fault (see later) as identified during the latest phase of exploration

törés elhagyásával. BALLA et al. (1997) a regionális jelentőségú, D jelú szerkezeti elemet Kapos-Szolnok vonalnak nevezi, amely keleten az alföldi fliszónába csatlakozik (BALla 1988). A térkép világosan mutatja, hogy a Kaposvonal nyugati részének kivételével minden további vető mentén érdemi „,kiújulási öv” jelentkezik ,,a szelvények legmagasabb szintjén". Másképpen: a kutatási területet - a Kapos-vonal nyugati részének kivételével — markáns neotektonikus vetőaktivitás jellemzi már a legkorábbi szeizmikus értelmezés alapján is.

Alapvonásait tekintve a fenti szerkezeti képet erősítették meg más tanulmányok eredményei is (HoRvÁTH et al. 1990, 1993). A modern olajipari szeizmikus adatokat is figyelembe vevő utolsó neotektonikai szintézis (BADA et al. 2005) a korábbi eredményeket pontosítva adta meg a Kapos-vonal lefutását és az abból kiágazó vetőágakat a vizsgálati területen (3. ábra). A bemutatott térképek közt kisebb-nagyobb eltérés mindenekelőtt a Kapos-vonalhoz csatlakozó kisebb vetőágak számában, helyzetében és geometriájában jelentkezik. Érdemes megfigyelni továbbá a Kapos-vonal nyugati szegmensének enyhe irányváltását ( $\mathrm{K}-\mathrm{Ny}$ ) a keletihez képest (KÉK-NyDNy) is, amelyet a korábbi vetőtérkép nem jelez (vö. 2. ábra). A kutatási terület DNy-i részén (Medina, Szedres és Tolna térségében; 3. ábra) BADA et al. (2005) térképe jelentős számban tüntetett fel ÉNy-DK-i csapású szerkezeti elemeket.

Az alapvonásokban lényegében megegyezô szerkezeti kép dacára markáns véleménykülönbség állt fent a kutatók közt a negyedidőszaki tektonikai aktivitás megítélésének kérdésében (RÁNER et al. 1997, MAROSI \& SCHWEITZER 1997, BALla et al. 1997, BALla 1999, Tóth \& HoRvÁTH 1997, 1999). Az ellentétes értelmezés lehetősége mindenekelőtt abból adódott, hogy a terület legfiatalabb (negyedidőszaki) képződményeit ért deformációk sem felszíni geológiai megfigyelésekkel/térképezéssel, sem pedig geofizikai mérésekkel nem voltak jól leképezhetők. Figyelembe véve a vetőkkel intenzíven felszabdalt pannóniai rétegek és a fedő negyedidőszaki összlet közötti igen jelentős eróziós diszkordanciát (vö. $5 a-b$. ábra) a szerkezetek korának megítélése és a vetődések menti oldalirányú elmozdulás mértékének a meghatározása is komoly problémát jelentett.

Az 1990-es évek elejére kialakult vitás helyzet megnyugtató rendezését kísérelte meg a brit OveArup \& Partners International cég által koordinált PHARE projekt, amely a Nemzetközi Atomenergia Ügynökség (NAÜ) felügyelete mellett valósult meg. Legfontosabb megállapítása szerint a telephely alatti pannóniai képződ- 


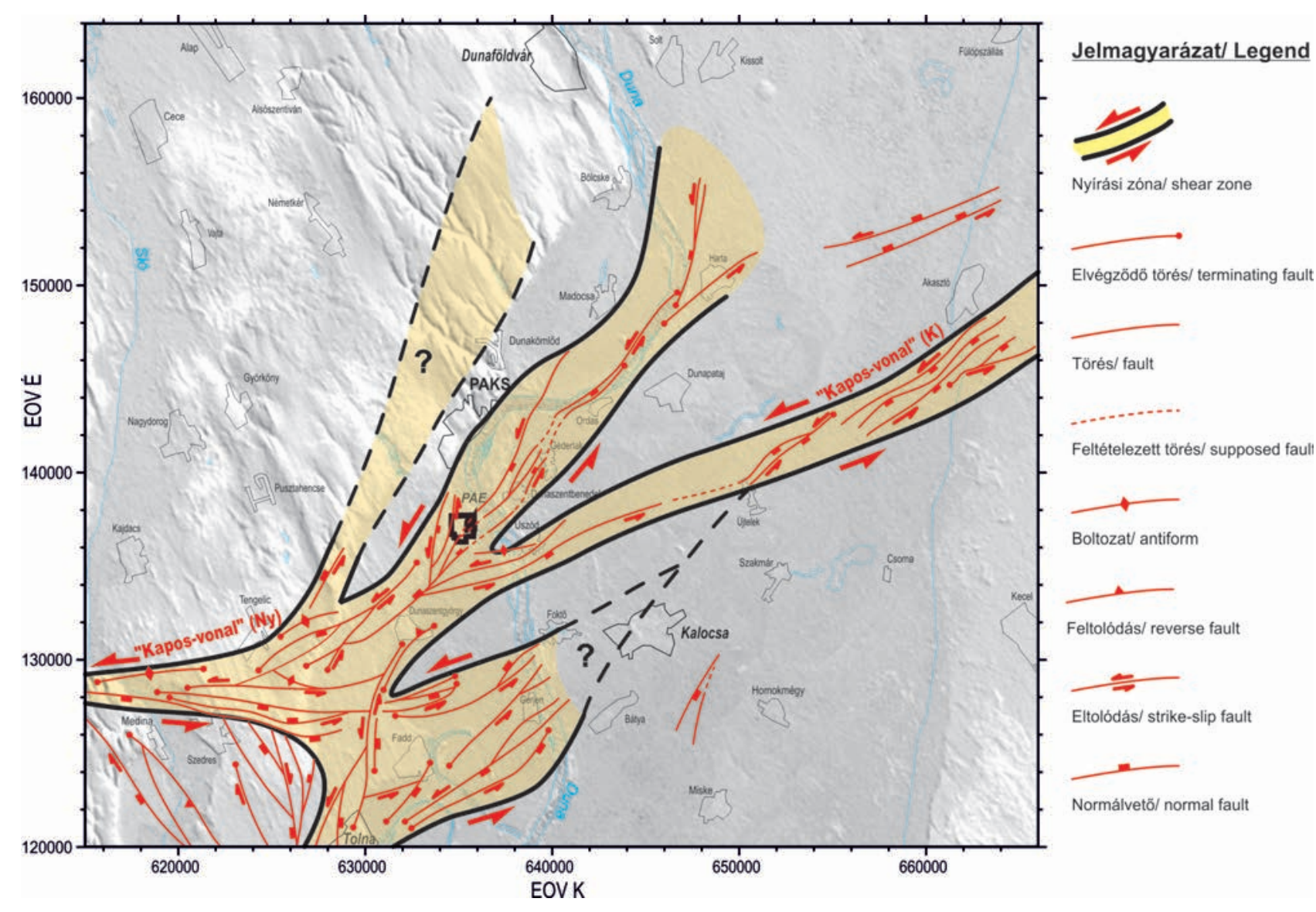

3. ábra. BADA et al. (2005) az olajipari szeizmikus adatokat is figyelembe vevő tektonikai szintézise a kutatási területről

Figure 3. Tectonic synthesis (BADA et al. 2005) of the study area using also seismic data related to hydrocarbon exploration

ményeket feldaraboló törészóna nagy valószínúséggel nem tekinthető aktívnak a negyedidószak során, mivel nem volt vitathatatlan megfigyelési adat ilyen korú képződmények tektonizáltságára (OvEARuP 1996). A kis valószínúséggel bekövetkező események konzervatív kezelése miatt azonban a vetômúködés negyedidőszaki felújulásának lehetôségét 10\%-nak tételezték fel a valószínúségi veszélyeztetettség analízis során.

E főbb kutatástörténeti előzmények után került sor a Paks II atomerômúvi beruházás földtani kutatási programjához (FKP) kapcsolódó újabb részletes földtanigeofizikai vizsgálatokra 2015-2016 során. A munkánkban bemutatott eredmények e kutatás keretében születtek. A kutatási eredmények Paks II honlapján 2016 ősze óta minden érdeklődő számára elérhetốk (http://www.paks2.hu/hu/ Kozerdeku/KozerdekuDokumentumok/telephelyengedelye zes/telephely_engedelyezes/Documents/TBJ_2k_5f.pdf). $\mathrm{Az}$ alábbiakban a legújabb kutatási eredmények tükrében egyrészt jellemezzük a kutatási terület szerkezeti/ mélyföldtani alapvonásait és diszkutáljuk/pontosítjuk a korábbi szerkezeti modelleket. Másrészt áttekintjük és elemezzük a neotektonikus fejlódési szakasz szempontjából kulcsfontosságú eredményeket, különös tekintettel a negyedidőszaki vetőaktivitás kérdésére.

\section{A kutatás során felhasznált módszerek és adatbázis}

A legnagyobb volumenú geofizikai kutatást a Paks kb. $300 \mathrm{~km}^{2}$ területú körzetében megvalósított 3D szeizmikus felvételezés jelentette. A terepi adatok feldolgozását a Geomega Kft. végezte, melynek legfőbb eredményét az összegzés utáni (post-stack) és összegzés előtti (pre-stack) migrált adattömbök, továbbá az előbbiből számított koherencia adattömb jelentették (WóRum et al. 2015). A felhasznált komplex geofizikai-geológiai adatbázis (4. ábra) magába foglalta (i) az új 3D mérést, (ii) a kutatás során lemélyült új szerkezetkutató fúrásokat (PAET-26, -27, -29, $-30,-34$ és -35), továbbá (iii) az értelmezéshez szintén felhasznált korábban és újonnan mért 2D reflexiós szeizmikus szelvényeket és (iv) archív fúrásokat is. Mindezen integrált geofizikai-geológiai adatrendszerek — az alapvetó jelentőségú, georeferált geológiai-geofizikai térképekkel együtt — képezték az elvégzett horizont- és vetőértelmezés alapját.

A bemutatott szeizmikus adatrendszeren elvégzett értelmezés és térképezés célja a földtani felépítést meghatározó rétegtani egységek (1. „Mélyföldtani viszonyok” fejezet) határának követése és az ezeket deformáló vetők 


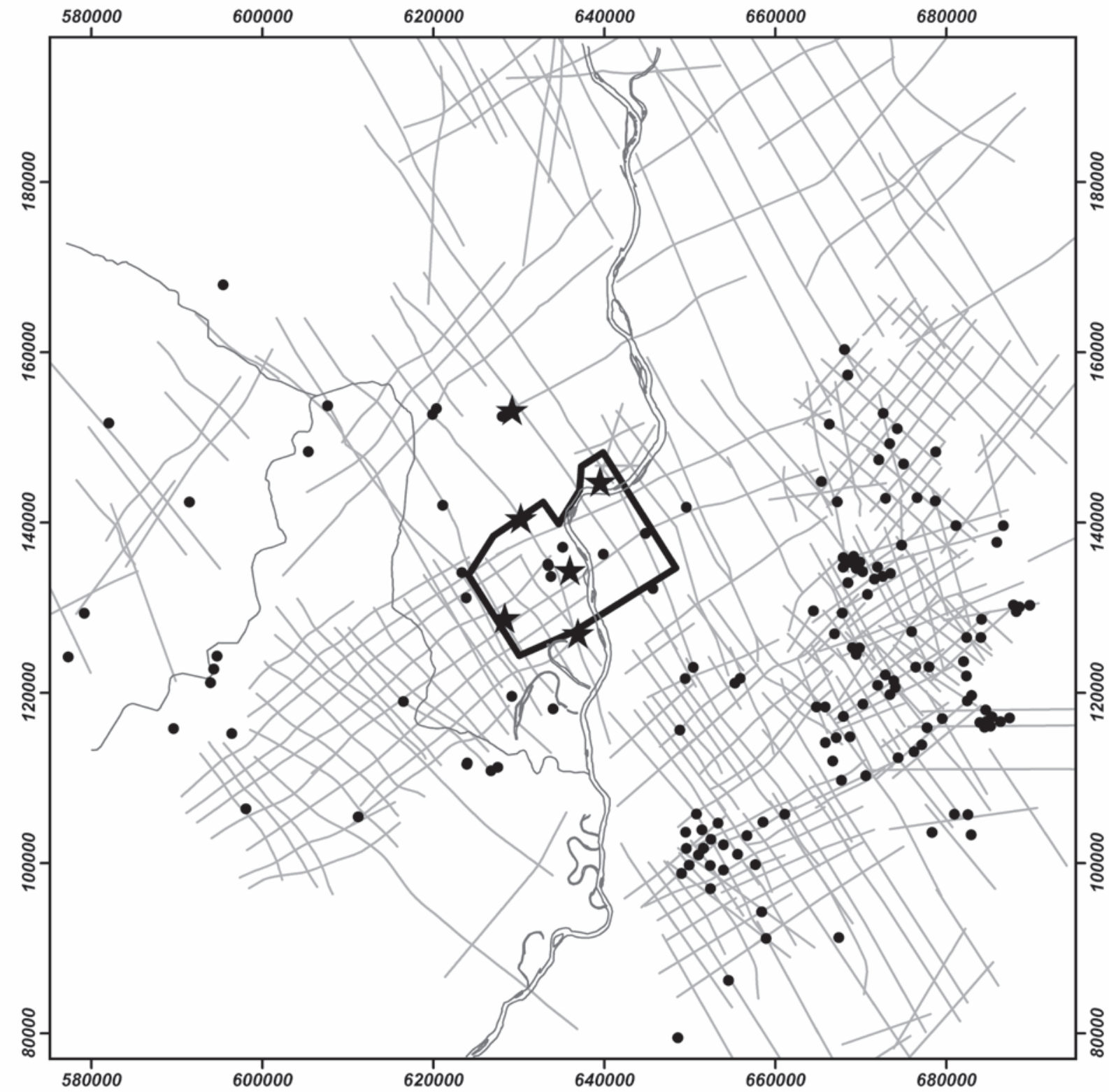

4. ábra. A szeizmikus értelmezéshez felhasznált komplex adatrendszer helyszínrajza (EOV koordinátarendszer): új 3D szeizmikus adattömb (fekete poligon), 2D szeizmikus szelvények (szürke vonalak), archív fúrások (fekete pontok), a kutatás során mélyült új szerkezetkutató fúrások (fekete csillag) Figure 4. The location of the integrated geophysical \& geological dataset used during seismic interpretation (EOV coordinate system): new 3D seismic cube (black polygon), 2D seismic lines (gray lines), archive wells (black dots) and new stratigraphic wells (black stars)

térbeli rendszerének meghatározása volt. Az időszelvényeken végrehajtott értelmezés után a kapott időtérképeket a kutatás keretében mért új VSP adatok felhasználásával mélységskálára transzformáltuk, annak szigorú figyelembevételével, hogy az értelmezett réteghatárok egyezzenek meg az archív és az új fúrásokban megismert tényleges réteghatárokkal. Az eredmények alapján alakítottuk ki a kutatási terület új, geológiailag és geometriailag egyaránt konzisztens 3D földtani-tektonikai modelljét. E 3D modell az integrált geofizikai-geológiai adatrendszerben megismert földtani-tektonikai valóság célorientáltan egyszerúsített változata, hiszen annak elemei egyúttal a kutatások során elvégzett különféle modellszámítások bemeneti adatrendszereit is képezték. A kialakított 3D földtani-tektonikai modell jelen munka szempontjából legalapvetőbb eredményeit a „Mélyföldtani viszonyok” fejezetben tárgyaljuk.

Az új 3D szeizmikus méréssel kapcsolatban az volt az elvárás, hogy a térben folyamatos leképzés eredményeképpen jobban megismerhető legyen a medencealjzat, pontosabbá váljék a vetőzónák rendszerének meghatározása és az idôsebb (kora- és középső-miocén) és a fiatalabb (pannóniai és fiatalabb) vetők kapcsolatának és geometriájának térképezése. A kutatási tapasztalatok szerint ugyanis a fiatal vetőaktivitás jellemzően a mélyebb sztratigráfiai szintekben gyökerező, idős vetők felújulásához kötődik. 
Ebből következően a fentiek megvalósulása teremtette meg annak lehetôségét, hogy a fiatal vetôk felszínközeli megjelenését alkalmasan lokalizált, nagyfelbontású 2D geofizikai mérésekkel — szárazföldi P és $\mathrm{S}$ hullám reflexiós szelvényezések, dunai pszeudo-3D szeizmikus mérések és multielektródás geoelektromos (MUEL) szelvényezések (áttekintő összefoglalásukat lásd Tóтн 2016) — megismerjük.

A feljebb ismertetett 2D és 3D szeizmikus adatrendszereken (4. ábra) térképezett vetők felszínközeli geometriájának és ezúton az aktivitás korának pontosabb megértéséhez az MFGI nagyfelbontású P-hullám reflexiós méréseket végzett 9 db szelvény mentén, együttesen 30 km összhosszúságban (KovÁcs et al. 2016). Ezt követôen került sor a 2D Shullám sekélyreflexiós szeizmikus szelvények kijelölésére és lemérésére. Ez utóbbiak azért voltak kiemelkedő jelentőségúek, mert — szemben a 2D P-hullám reflexiós szeizmikus szelvényekkel — a negyedidőszaki rétegeket is megfelelő minőségben képezték le. Ezáltal lehetőség nyílott a kutatástörténeti áttekintésben is említett negyedidőszaki tektonikai érintettség kérdésének adekvát vizsgálatára. Az S-hullám reflexiós szeizmikus szelvények a nagyfelbontású 2D Phullám reflexiós szeizmikus szelvények azon szakaszain kerültek kijelölésre, melyeken a leképezett legfiatalabb rétegeket is harántoló vetők voltak azonosíthatók. Ugyancsak a nagyfelbontású P-hullám reflexiós mérések eredményeire is támaszkodva került sor a MUEL tomográfiás szelvényezésre (Geomega Kft.) összesen 11 db geoelektromos szelvénnyel. Ez utóbbi módszer szárazföldi területen tudja leképezni a kôzetek elektromos fajlagos ellenállásának változásait a fizikai felszíntől néhányszor 10 méteres mélységig. A módszer az egyébként nehezen leképezhetô negyedidőszaki képződmények belsô felépítésérôl és szerkezetérôl nyújtott tehát további részletes adatokat, amelyek a 2D S-hullám sekélyreflexiós szeizmikus szelvények értelmezése során is fontos támogatást jelentettek.

Nagyfelbontású vízi szeizmikus mérésre a Dunán került sor, hiszen a térképezett, kiemelkedő jelentőségú vetők egy része a kutatási területen áthalad a folyó alatt. Speciális egycsatornás eszközzel, nagyfrekvenciás hanghullámok segítségével és néhány méteres szelvényközzel felvételezve közvetlen a mederfenéktől néhány méter mélységig ,,pszeudo-3D” leképzés valósítható meg (áttekintésért l. Wórum et al. 2016). Időigénye és technikai kivitelezésének bonyolultsága miatt ilyen sứrúségú felvételezést csak limitált terjedelemben lehetett megvalósítani, ezért a mérésre alkalmasan kiválasztott területrészeken (ún. mérési blokkokban) került sor, messzemenóen figyelembe véve a 2D és 3D szeizmikus adatrendszereken elvégzett vetőtérképezés eredményeit.

A feljebb tárgyalt valamennyi nagyfelbontású geofizikai mérés eredményét is integráltuk a kiértékelés során felépített projektbe, amely az egységes értelmezés lehetőségét biztosította a teljes geofizikai-geológiai adatrendszeren, ideértve az eredmények közt említett kutatóárkot is, amelynek munkálatait és eredményeit Ács et al. (2016) munkája tárgyalja részletesen (2.1.4.2 és 3.1.2.3 fejezetek). A nagyfelbontású 2D és ,pszeudo-3D” geofizikai mérések legfőbb eredményeit — a teljesség igénye nélkül — a „Neotektonikai észlelések" fejezetben ismertetjük, mindenekelőtt a fő tektonikai következtetésekre koncentrálva.

\section{Eredmények}

\section{Mélyföldtani viszonyok}

Az előző fejezetben bemutatott 2D-3D szeizmikus adatrendszeren öt, a terület földtani felépítésében kiemelkedő szerepú, regionális geológiai határfelület — prekainozoos aljzat-tető, alsó-miocén tető, középső-miocén tető, Endrődi-tető, Algyői-tető — térképezésére került sor. Ezek rétegtani definícióját és kronológiai viszonyait, továbbá a terület sematikus tektono-sztratigráfiai modelljét az 5a-b ábrák mutatják be. E geológiai horizontok, továbbá a szintén térképezett vetôrendszerek képezték a kialakított 3D földtani-tektonikai modell két alapvető, mélységkonvertált téradatrendszerét. Ezek egyes elemei földtanilag és geometriailag egyaránt konzisztens 3D adatrendszereket képviselnek.

Terjedelmi okok miatt e munkában nincs mód a 3D földtani-tektonikai modell valamennyi elemének részletes ismertetésére. A továbbiakban ezért a mélyföldtani felépítés alapvonásait néhány kiválasztott horizont mélységtérképével, illetve tömbdiagramjával szemléltetjük (6-7. ábrák). Bemutatunk továbbá egy, a kutatási területet ÉNyDK-i irányban harántoló, a földtani felépítés legfontosabb jellemzőit jól illusztráló földtani szelvényt is (8. ábra), amelyet a 3D földtani-tektonikai modell felhasználásával szerkesztettünk.

Bár munkánk fókuszában mindenekelőtt a szerkezeti viszonyok ismertetése áll, azonban ezzel igen szoros kapcsolatban állnak a legalapvetőbb földtani vonások, így tárgyalásunkban röviden azokra is kitérünk. A 3D földtanitektonikai modell a kutatási területen meghatározó szerepú vetôket tartalmazza, így a további, a modell alapján készült illusztrációk a lokális jelentőségú, kisebb vetőket nem tüntetik fel, jóllehet ezeket is azonosítottuk és értelmeztük munkánk során. Fontos továbbá kiemelni, hogy a kutatás során azokat a vetőket tekintettük neotektonikusan aktívnak, amelyek a szeizmikus szelvényeken a pannóniai selfprogradációt jelölő Algyői Formáció ( $5 a-b$ ábrák) tetőhorizontját jól észlelhetően átmetszették/elvetették (vö. 7. ábra). A tapasztalatok szerint e vetôk döntő többsége az Algyői Formációnál fiatalabb pannóniai képződményekben is érdemi, a szeizmikus adatrendszereken jól észlelhető deformációt hozott létre, s jelentős területi kiterjedésben a kvarter/pannóniai diszkordancia felületig, illetve annak közelébe hatoltak (vö. 14. ábra).

A 3D földtani-tektonikai modell egyik legfontosabb, és egyben a legmélyebb helyzetú térképezett elemét a prekainozoos aljzattető alkotja, amely egy alapvető fontosságú unkonformitást (1. jelû diszkordancia-felület, $5 a-b$ ábrák) jelöl. Alább e geológiai horizont mélységtérképét, az azon meghatározott vetőrendszereket, valamint az elkülönített aljzatmorfológiai elemeket mutatjuk be (6. ábra). 


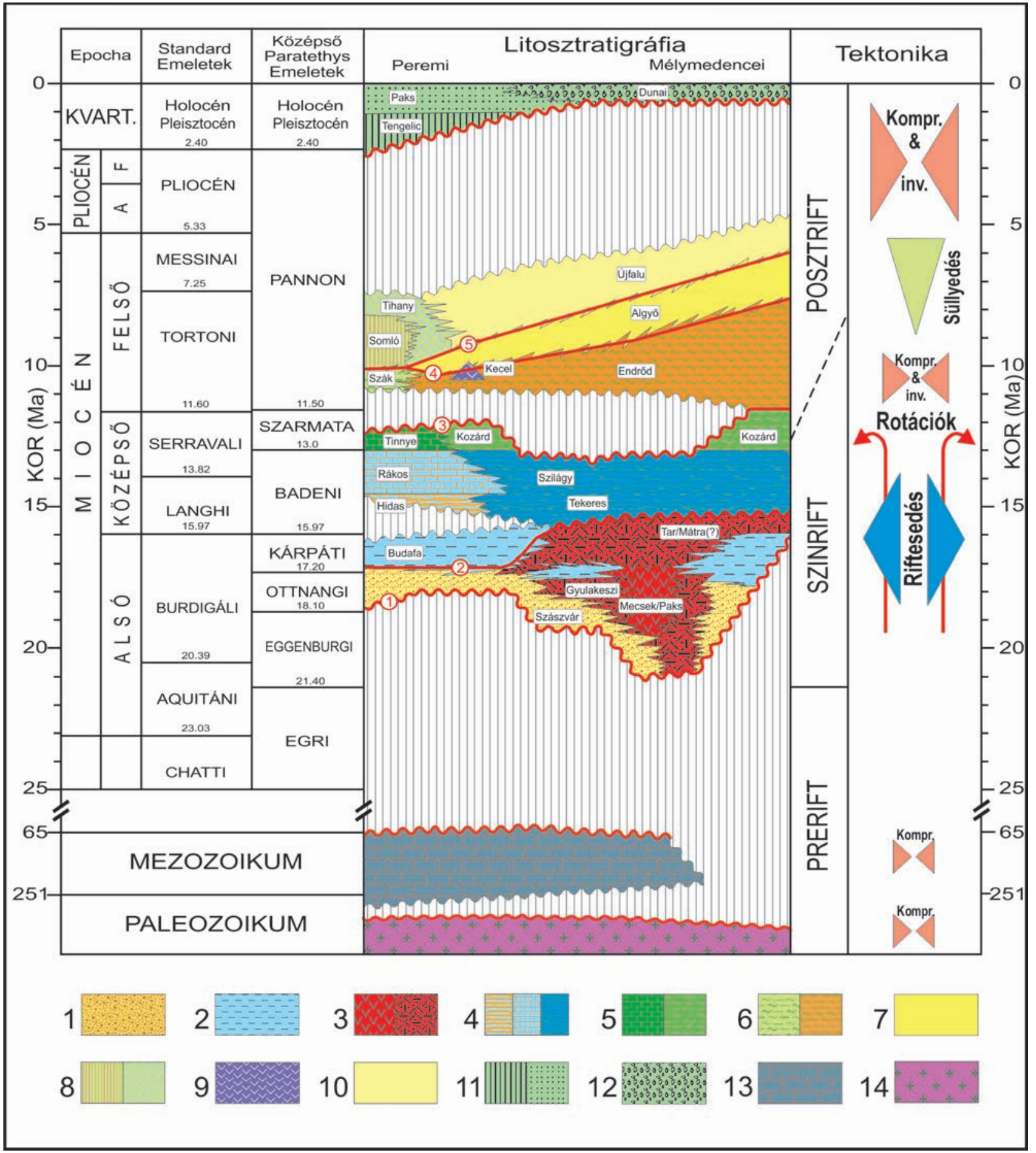

5a ábra. A kutatási terület képződményeinek áttekintő időrétegtani diagramja (módosítva HoRváTH et al. [2015] után, és MAGYAR et al. [e kötet] eredményeinek figyelembevételével). A számozott (1-5) piros vonalak a 3D földtani modellben szereplő, a szeizmikus adatrendszeren (4. ábra) regionálisan térképezett horizontok időrétegtani helyzetét mutatják. Litosztratigráfia: álló felirat - formáció, dőlt - tagozat

1. tavi-folyóvízi képződmények 2. abráziós képződmények 3. szubvulkáni andezit, illetve riolit-és riodácit ártufa 4. tengerparti szenes-márgás képződmények és biogén mészkövek, illetve nyilttízi aleurolitos-márgás és agyagmárga 5. brakkvízi biogén mészkő és homokos agyagmárga, mészmárga 6 . tavi medenceperemi márga és nyiltvízi agyagmárga-mészmárga 7. tavi progradáló és aggradáló selflejtő képződmények 8. medenceperemi és mocsári agyagmárga-, homok-, lignitrétegek 9. Keceli Bazalt Formáció 10. delta és alluviális síkságon képződött agyagmárga, aleurolit és homokkő 11. Negyedidőszaki lösz-paleotalaj rétegsor (Paksi Formáció) és alatta települỏ vörösagyag (Tengelici Formáció) 12. Felsö-pleisztocén-holocén folyóvízi homok és kavicsos homok 13. Permo-mezozoos képződmények 14. Paleozoos kristályos kőzetek.

Figure 5a. Stratigraphic chart of the geological formations occurring in the study area (modified after HORVÁTH et al. [2015], considering also the results of MAGYAR et al. [this volume]). Numbered red lines (1-5) show the position of the regional geological horizons mapped on the seismic dataset (Figure 4) and subsequently integrated into the 3D geological-structural model of the area. Lithostratigraphy: normal letters - formation, italics- member

1. Fluvial and lacustrine rocks 2. Abrasional formations 3. Subvolcanic andesite \& rhyolitic to rhyodacitic ignimbrite and tuff 4. Marine coastal coal-bearing, marly formations \& biogenic limestone and open marine silty claymarl 5. Brackish biogenic limestone \& sandy claymarl, calcmarl 6. Lacustrine marginal marl \& deep basinal claymarl/calcmarl 7. Lacustrine shelf slope silty/marly formations 8. Basin marginal and marshy claymarl, sand and lignite 9. Kecel Basalt Fm 10. Claymarl, silt-\& sandstone deposited on delta and alluvial plain 11. Quarternary loesspalaeosoil series (Paks Fm) underlying by red clay (Tengelic Fm) 12. Upper Pleistocene - Holocene fluvial sand and gravelly sand 13. Permo-Mesozoic formations 14. Palaeozoic crystalline rocks 


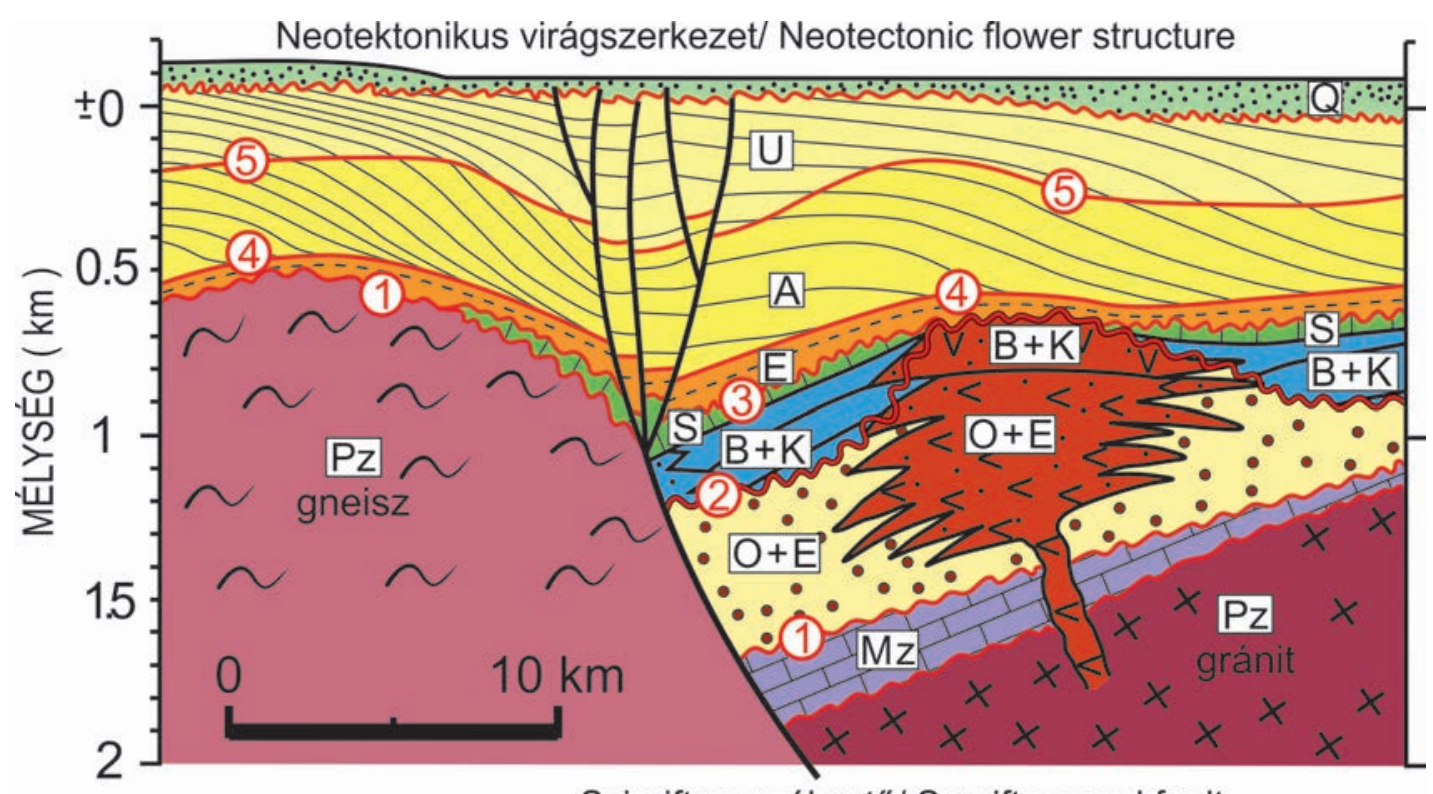

Szinrift normál vetö/ Synrift normal fault

5b ábra. A kutatási terület elvi földtani szelvénye a 3D földtani modellben szereplő térképezett geológiai horizontokkal, illetve unkonformitásokkal: (1) a medencealjzat teteje, (2) kontinentális törmelékes/vulkáni miocén tető, (3) tengeri miocén tető, (4) Endrőd-tető, (5) Algyő-tető $\mathrm{Q}$ = negyedidőszaki képződmények; $\mathrm{U}=$ Újfalui Form.; $\mathrm{A}$ = Algyöi Form.; $\mathrm{E}$ = mélymedencei pelitekből felépülő Endrődi Form.; $\mathrm{S}$ = szarmata képződmények; B+K = tengeri partszegélyi és nyíltvízi badeni és kárpáti rétegek; $\mathrm{O}+\mathrm{E}=$ alsó-miocén ottnangi és eggenburgi törmelékes összlet; $\mathrm{K}+\mathrm{B}=$ kárpáti Tari Dácittufa és badeni Mátrai Andezit Form.; O+E = ottnangi(?) és eggenburgi Gyulakeszi Riolittufa és Mecseki(/Paksi) Andezit Form.; Mz/Pz= mezozoos, illetve paleozoos aljzat

Figure 5b. Schematic geological cross section of the study area showing also the mapped regional geological horizons/unconformities-(1) top preCenozoic basement, (2) top of continental Miocene clastics/volcanics, (3) top of marine Miocene, (4) top-Endröd, (5) top-Algyö - constituting the $3 D$ geological-structural model of the area

$Q=$ Quarternary formations; $U=U$ Úfalu Form.; $A=$ Algyö Form.; $E=$ Endrödi Form. consisting of deep basinal marls; $S=$ Sarmatian formations; $B+K=$ marine coastal and open marine Badenian és Karpatian formations; $O+E=$ Lower-Miocene Ottnangian and Eggenburgian siliciclastics; $K+B=$ Karpatian Tar Dacite Tuff and Badenian Mátra Andesite Form.; O+E = Ottnangian(?) and Eggenburgian Gyulakeszi Rhyolite Tuff and Mecsek(/Paks) Andesite Form.; Mz/Pz = Mesozoic and Palaeozoic basement rocks

A térkép alapján a kutatási területen a pre-kainozoos aljzat erôsen tagolt morfológiájú, számos kisebb-nagyobb magaslat és süllyedék különíthetô el, amelyek esetében fôként a terület északi részén — szembeötlő a gyakori ÉKDNy-i irányítottság, míg É(É)Ny-D(D)K-i irányítottság csak ritkábban, jellemzően a terület déli részén fordul elő (lásd még alább). A süllyedékekben a változatos litológiai kifejlődésú, az 1 km-t sokszor jócskán meghaladó vastagságú alsó-miocén szárazföldi törmelékes, illetve magmás (vulkáni) képződmények ( $5 a$ és $5 b$ ábrák) lényegében mindenhol jelen vannak, míg az aljzatmagaslatokról többnyire hiányoznak (8. ábra). E képződmények a fúrási adatokon túl elsôsorban a jellegzetes zavart/kaotikus szeizmikus fácies alapján különíthetôek el a felettük települő, jellemzően jól követhetô, rétegzett belső szerkezetet mutató, tengeri középsô-miocén (főként szarmata-badeni) összlettől. Az új szerkezetkutató fúrások vulkáni kőzetanyagán végzett geokronológiai vizsgálatok eredményei (HARANGi 2016a, b) egyértelmúen igazolták a kora-miocén magmás tevékenység kiemelkedő szerepét a vizsgált területen (8. ábra), megerősítve a megelőző szeizmikus térképezés során kialakult, erre vonatkozó hipotézist.

Az alsó-miocén képződmények felett települő tengeri középső-miocén összlet a kutatási területen, néhány aljzatmagaslat kivételével, általános elterjedésú (8. ábra). A kisebb-nagyobb süllyedékek — helyenként ugyan némi térbeli eltolódással — többnyire követik a kora-miocénben kialakult fő üledékgyưjtő zónákat. A depocentrumokban a feljebb tárgyalt alsó-miocén vastagságviszonyokhoz képest lényegesen kisebb átlagos vastagság (jellemzően 200-500 m között) figyelhetô meg, míg a jelentôsebb süllyedékek közti területen a középső-miocén üledékek jellemzően vékony „lepelként” (<100-150 m) települnek az idôsebb miocén, illetve a különböző prekainozoos képződményekre (8. ábra). Mindez a terület mérsékelt ütemú süllyedését jelzi a középső-miocén során, viszonylag intenzívebb süllyedés csak a kora-miocénben létrejött vetők mentén történt. Ez utóbbiak részben már meglévő, a variszkuszi és/vagy kréta orogenezishez kötődő, jellemzően ÉK-DNy-i irányítottságú aljzati struktúrákhoz is kapcsolódhattak, hiszen ez az aljzati irányítottság (HAAs et al. 2010, illetve Szerkezetalakulás fejezet) a későbbi szerkezetalakulási fázisok során is érdemi preformációt képezhetett lokálisan.

A késő-miocén (pannóniai) elejére a bemutatott aljzatmorfológiai képhez alapvonásaiban hasonló, de annál jóval kisimultabb, kevésbé tagolt morfológia jött létre a kora- és középső-miocén ciklus során végbement „feltöltés” eredményeként (8. ábra). A pannóniai ciklus során a legintenzívebben süllyedő részterületeket a Bonyhádi-medence, az Ozorai-árok, a Keceli-árok, továbbá a Fajszi- és Borotaisüllyedékek jelentik (6. ábra). Ezekben jelentős, helyenként akár a 200-300 métert is elérő vastagságban rakódott le az 

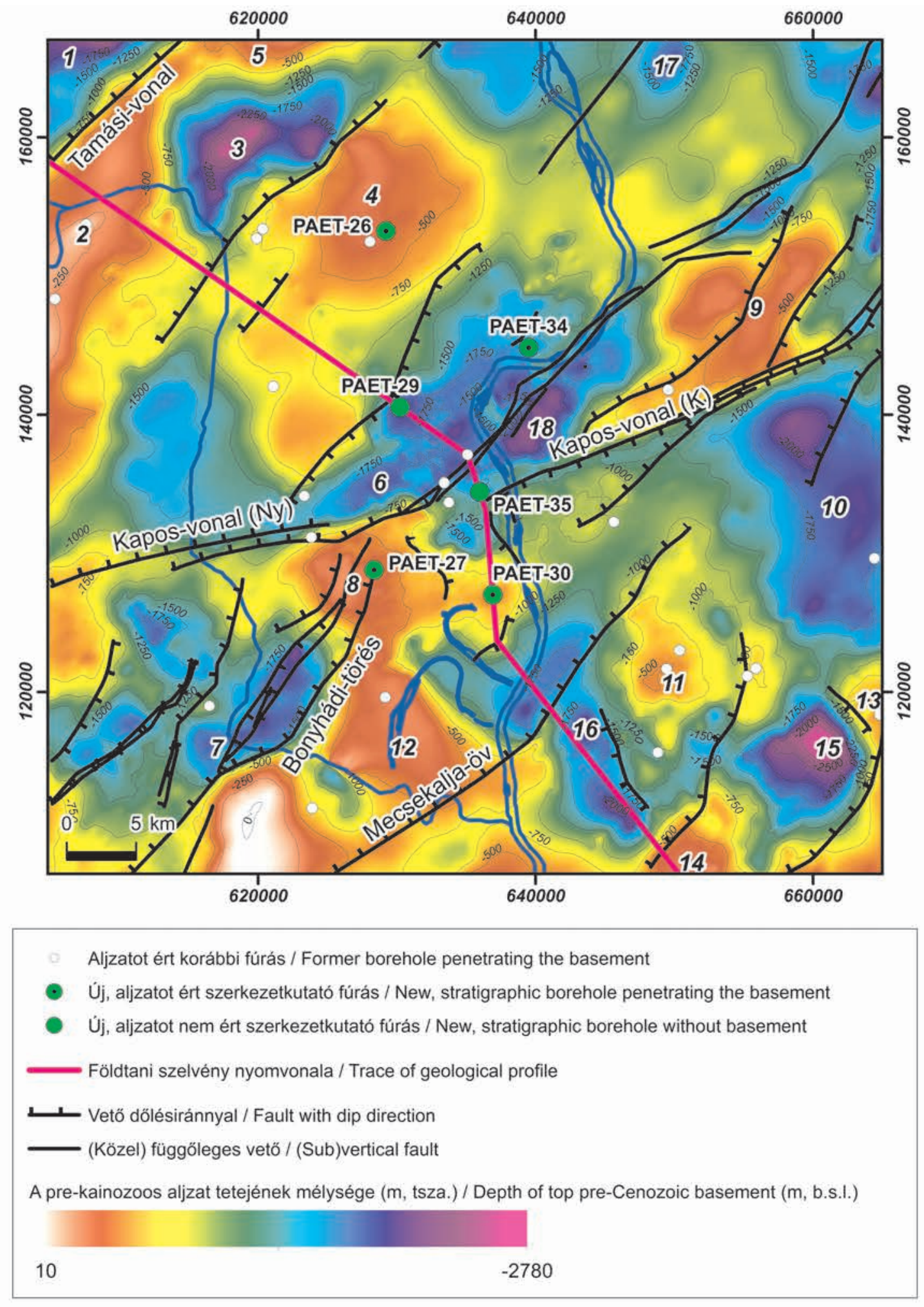

6. ábra. A prekainozoos aljzattető mélységtérképe a főbb aljzatmorfológiai elemek és vetőrendszerek feltüntetésével (EOV koordinátarendszer). A földtani szelvényt (lila vonal) a 8. ábra mutatja be

1. Ozorai-árok 2. Tamási-magaslat 3. Simontornyai-süllyedék 4. Németkéri-magaslat 5. Sárbogárdi-magaslat 6. Tengelic-Paksi árok 7. Bonyhádi-süllyedék 8. Tolnai-magaslat 9. Szentkirályi-magaslat 10. Keceli-árok 11. Miskei-magaslat 12. Mórágy-Szekszárdi-magaslat 13. Jánoshalmai-magaslat 14. Sükösdimagaslat 15. Borotai-süllyedék 16. Fajszi-árok 17. Újsolti-árok 18. Géderlaki-árok

Figure 6. Depth map of the pre-Cenozoic basement showing also the main basement morphological elements (numbers), as well as mapped fault systems (EOV coordinate system). The indicated geological profile (magenta line) is shown on Figure 8

1. Ozora trough 2. Tamási high 3. Simontornya basin 4. Németkér high 5. Sárbogárd high 6. Tengelic-Paks trough 7. Bonyhád basin 8. Tolna high 9. Szentkirály high 10. Kecel trough 11. Miske high 12. Mórágy-Szekszárd high 13. Jánoshalma high 14. Sükösd high 15. Borota basin 16. Fajsz basin 17. Újsolt trough 18. Géderlak trough 


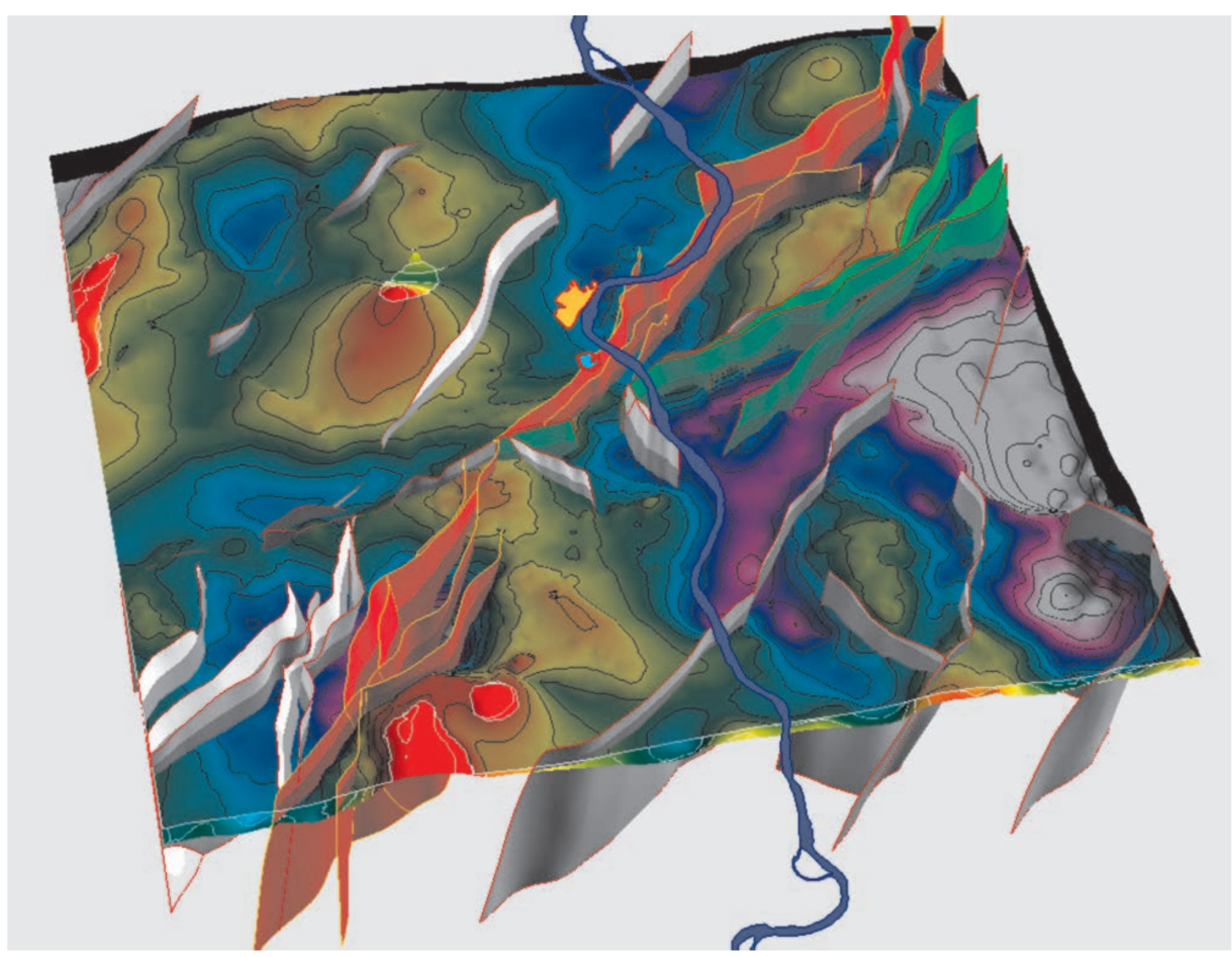

7. ábra. A 3D földtani modell perspektivikus nézete DDK felől a pannon fekü (színezett) és az Algyői Formáció tetejének (transzparens) horizontjaival, valamint a vetőfelületekkel. Pirossal jelölt vetök: Bonyhád-Dunaszentgyörgy-Harta, zölddel jelölt vetök: Kapos-Kelet neotektonikus deformációs zóna

Figure 7. Oblique view of the 3D geological-structural model from the SSE showing the base Pannonian (coloured) and top Algyö Formation (transparent) horizons, as well as mapped fault surfaces. Red faults: Bonyhád-Dunaszentgyörgy-Harta, green faults: Kapos-East neotectonic deformation zones

Endrődi Márga. A nagyobb süllyedékek mellett kisebb, elnyúlt (,szilvamag-alakú”), ÉK-DNy-i csapású vetőzónákhoz (pl. Dunaszentgyörgy-Harta vetôzóna, lásd alább) kapcsolódó, transztenziós eredetú pull-apart medencékben is intenzív üledékképződés zajlott. A kevésbé intenzíven süllyedô részterületeken a progradáló selfperem agyagosaleuritos képződményeivel (Algyői F.) indult a pannóniai üledékképződés, amely az egész kutatási területen általános elterjedésú, így az Endródi Márga felett is ez települ. A selfperem MAGYAR (2010) vizsgálatai alapján megközelítően 8,5-7 millió éve haladt át a kutatási területen. A selflejtő előtti mélymedencében lerakodó turbidites képzôdmények (Szolnoki F.) hiányoznak, ugyanis a kutatási területet a tágabb környezethez viszonyítva csak mérsékelt süllyedés jellemezte a pannóniai során. Az Algyői F. felett egységesen az Újfalui és Zagyvai Formációkba sorolt, jellemzően néhány száz méter vastagságú homokosagyagos képződmények települnek (8. ábra). Ezek felett jelentős szög- és eróziós diszkordanciával a meglehetősen vékony (max. pár $10 \mathrm{~m}$ vastag) negyedidőszaki üledékek következnek.
A kutatási terület szerkezeti képét tekintve meghatározó elem az aljzatban regionális skálán (medence léptékben) is jól követhető, KÉK-NyDNy-i irányítottságú „Kapos-vonal” (6. ábra). A ,vonalat" valójában meredek $\left(70-80^{\circ}\right.$-os) dőlésú törések alkotják, melyek a részletes térképezés szerint Dunaszentgyörgytôl nyugatra egy északi dólésú, keletre pedig egy déli dőlésú, viszonylag szúk vetőzónát alkotnak. E vetôszegmensek az átfedô rövid szakaszon sátorszerúen hajlanak egymáshoz (8. ábra). Míg a vonal keleti szegmense markáns neotektonikus aktivitást mutat a szeizmikus szelvényeken, addig a nyugati szakasz neotektonikusan lényegében inaktív a vizsgálati területen (vö. 7. ábra).

A „Kapos-vonaltól” északra azonosított vetôk, hasonlóan az aljzatmorfológiai elemek többségéhez, uralkodóan ÉK-DNy-i irányítottságúak (6. ábra). Közülük kiemelkedó jelentőségú a Közép-magyarországi vonal részét képező Tamási-vonal és a jelen kutatás során DunaszentgyörgyHarta vetőzónaként azonosított vetó, amelyet már a korábbi tanulmányok is jeleztek. Ez utóbbi a Kapos-vonal keleti szakaszával együtt a kutatási terület legintenzívebb neotektonikus aktivitást mutató szerkezeti eleme. Tipikus 


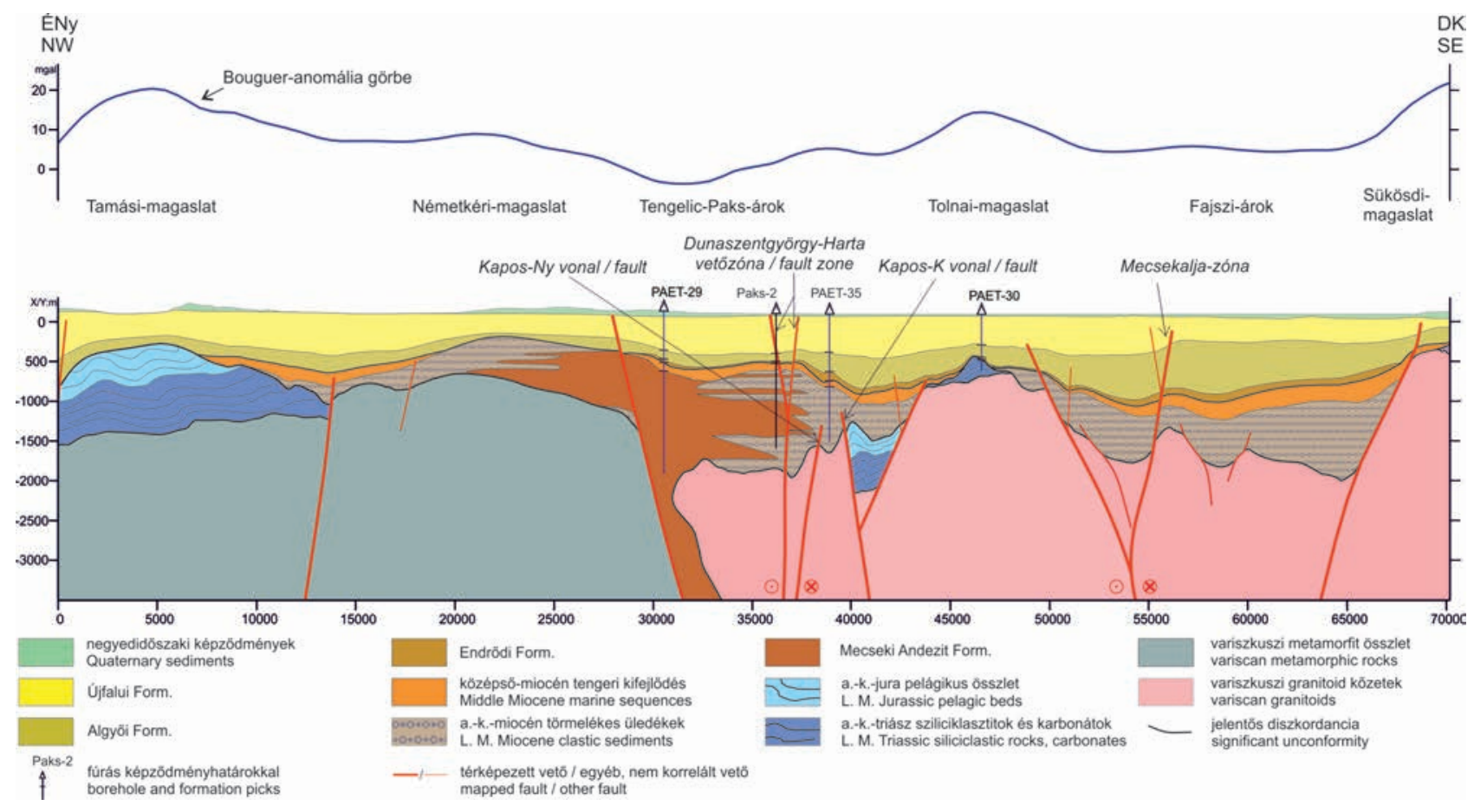

8. ábra. ÉNy-DK irányú földtani szelvény, amely a kutatási terület fő rétegtani egységeit és a vetőket mutatja. A szelvény felett kék színnel a Bouguer-anomália szelvénymenti lefutását tüntettük fel. A szelvény nyomvonala a 6. ábrán látható

Figure 8. NW-SE oriented geological cross section showing the main stratigraphic units and faults of the study area. Blue line above shows the Bouguer-anomaly curve along the section. The trace of the profile is shown on Figure 6

„virágszerkezetet” mutató belső struktúrájuk és a 3D adattömb idôsíkmetszeteiben jól megfigyelhető másodlagos kapcsolódó formaelemek (Riedel-törések) alapján e vetők oldaleltolódásnak minősíthetők a neotektonikus fázis során.

A „Kapos-vonaltól” délre is jellemzóek az ÉK-DNy-i csapású vetôk, de e részterületen más irányú, fơként (É)ÉNy(D)DK-i csapású vetők is megjelennek (6. ábra). A „Kaposvonaltól" délre megjelenô vetôk közül kiemelkedő jelentôségú a Bonyhádi-medence DK-i peremén húzódó, ÉK-DNy-i csapású mestervető (Bonyhádi-törés) és a hozzá csatlakozó, összességében hasonló irányú vetőrendszer, amely DNy felé a Mecsek északi pikkelyzónájának deformációs övéhez csatlakozik. E vetőzóna mind irányítottság, mind a szerkezeti jelleg és neotektonikai aktivitás szempontjából igen hasonló a Dunaszentgyörgy-Harta vetőzónához. A neotektonikai aktivitás tekintetében így lényegében egységesen viselkedő Bonyhád-Dunaszentgyörgy-Harta vetőrendszerról beszélhetünk (7. ábra). A Bonyhádi-törés mellett a déli részterületen regionálisan ugyancsak kiemelkedő jelentőségú szerkezeti elem a neotektonikusan szintén aktív (KONRÁD \& SEBE 2010) Mecsekalja-vonal (6-7. ábrák).

A Bonyhádi-törés kapcsán kell megemlíteni, hogy a PAET-27 fúrás (6. ábra) több mint 300 m vastagságban harántolt mezozoos képződmények alatt, éles szerkezeti kontaktussal, alsó-miocén törmelékes üledékes összletbe jutott, és abban is állt le (Ács et al. 2016: 2.1.3.2 fej., 16. ábra). A szeizmikus szelvények tanúsága szerint e deformáció a tengeri középső-miocén képződményeket már egyáltalán nem érintette, azok a mezozoos aljzatképződmények felett zavartalan üledékes kontaktussal települnek. Mindez a kora-miocén végén végbement transzpresszív/kompreszszív? jellegú szerkezetalakulást jelez. A szeizmikus szelvényeken helyenként megfigyelhető szögdiszkordancia az alsó- és tengeri középső-miocén képződmények határán (2. jelú geológiai horizont) ugyancsak e szerkezetalakulási esemény jelentőségére hívja fel a figyelmet.

A 3D földtani modell egyes elemeit térben is szemléltető perspektivikus megjelenítés (7. ábra) és a pre-kainozoos aljzat mélységtérképének (6. ábra) összehasonlítása alapján jól látható, hogy az általános vetômintázat igen hasonló a térképezett geológiai horizontokon, azaz a pannóniai rétegsort harántoló vetôk döntően a már jelenlévő aljzati vetők felújulásával képződtek a neotektonikai fejlődési szakaszban.

\section{Neotektonikai észlelések}

A lefolytatott kutatás tapasztalatai szerint a negyedidőszaki összlet tektonikus érintettségét csak kombinált, nagyfelbontású speciális geofizikai-geológiai vizsgálatokkal (S-hullám reflexiós szeizmika, nagyfelbontású elektromos tomográfia [MUEL], sekélyfúrások, árkolás) lehetett kielégítően alátámasztani/elvetni. E mérések kitûzésére és megvalósítására — ahogy ezt már a módszertani fejezetben is hangsúlyoztuk - a kialakított új 3D földtani-tektonikai modell, illetve a nagyfelbontású szárazföldi 2D P-hullám szeizmikus mérések eredményeinek maximális figyelembe- 
vételével került sor. A negyedidőszaki tektonikai aktivitás szempontjából kulcsfontosságú nagyfelbontású mérések/ vizsgálatok helyszíneit a 9. ábra foglalja össze.

A nagyfelbontású speciális vizsgálatok közül először a geoelektromos vizsgálatok eredményeit tárgyaljuk. Ezek a geofizikai szelvények egyrészt jól leképezték a pannonkvarter diszkordancia felületet, másrészt lehetővé tették a recens folyami üledékek finom- és durvaszemcséjü üledékes részegységeinek elkülönítését is. A nagyfelbontású 2D Phullám szeizmikus mérésekhez kapcsolódó 11 db MUEL szelvény mindegyike a pannóniai összletben észlelt vetôkkel jól korrelálható, markáns felszínközeli ellenállás anomáliákat mutatott (KUDó et al. 2016). Ezzel erôs támogatást adtak a negyedidőszaki üledékek (de legalábbis azok alsó tartomá- nyának) tektonikus érintettségére. A fajlagos ellenállások oldalirányú változásai azonban értelmezhetôk laterális litológiai kontraszttal is. Utóbbiak pedig a nagyon változatos fáciesú negyedidőszaki összletben súrún és előrejelezhetetlenül fordulhatnak elő, ezért a MUEL mérések nyújtotta eredményeket önmagukban még nem tekintettük perdöntőnek a negyedidôszaki tektonikai érintettség kérdésében. E mérések közül a MUEL-10 szelvényét mutatjuk be, amelyet összevetünk a vele gyakorlatilag azonos nyomvonalon futó, az ELGI által 1994-ben mért Pa-13/94 jelû, nagyfelbontású szárazföldi szeizmikus szelvénnyel is (10. ábra).

A Pa-13/94 szeizmikus reflexiós szelvényen jól látszó, a pannóniai/negyedidőszak diszkordancia felületet elérő vetővel — amely a 3D földtani-tektonikai modellben a Dunaszent-

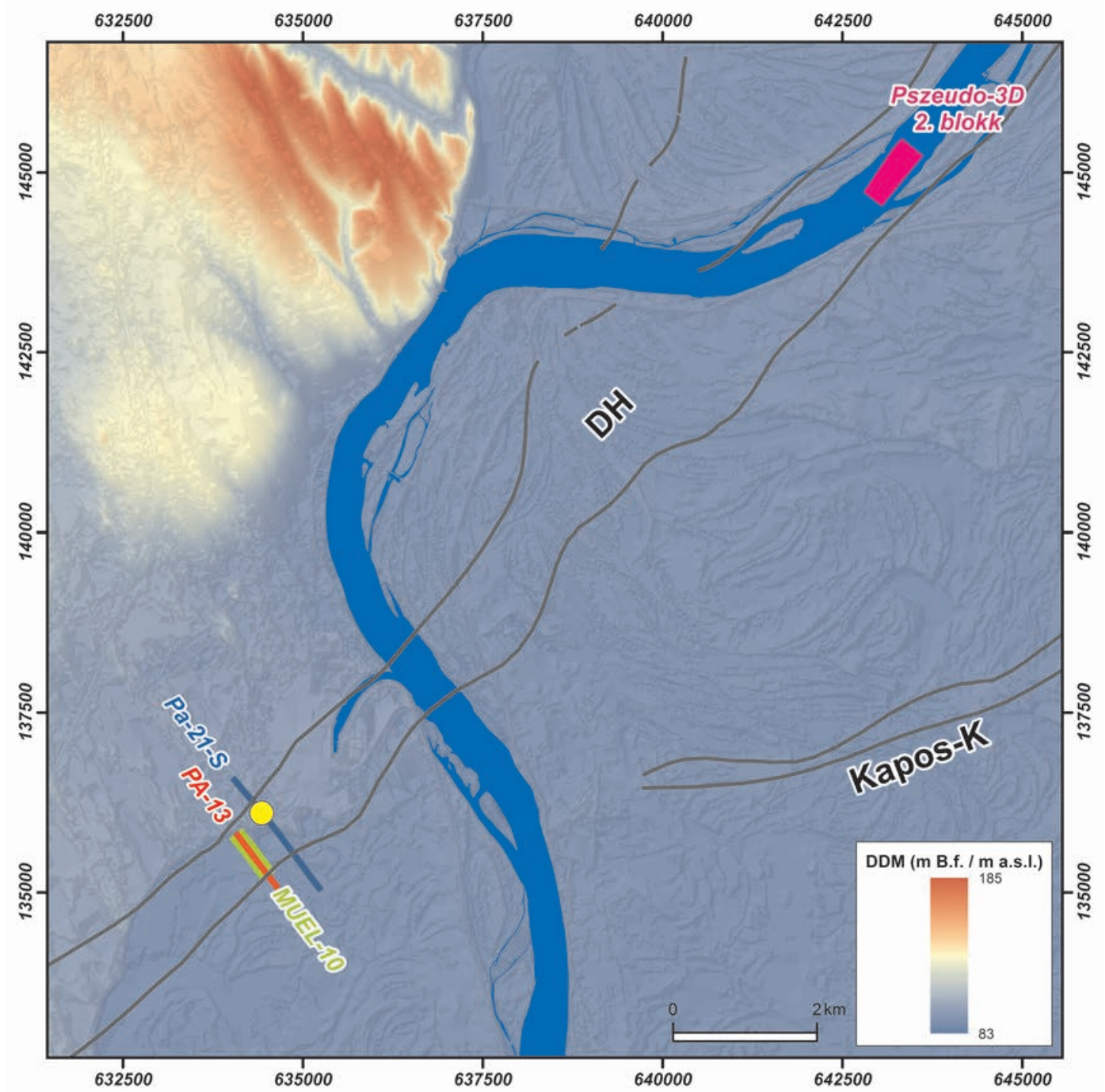

9. ábra. A bemutatott nagyfelbontású geofizikai mérések és a kutatóárok (sárga kör) helyszinrajza (EOV koordinátarendszer). Háttér: a kutatási terület digitális terepmodellje. Szürke vonalak: a kutatási terület legfontosabb neotektonikus vetỏzónáinak (DH: Dunaszentgyörgy-Harta vetőzóna, Kapos-K: a Kapos-vonal keleti szegmense) helyzete a negyedidőszaki képződmények bázisára vetítve a 3D földtani-tektonikai modell alapján

Figure 9. Overview map (EOV coordinate system) of the introduced high-resolution geophysical surveys and trench (yellow circle). Background: the digital elevation model (DEM) of the study area. Gray lines: location of the most important neotectonic fault zones (DH: DunaszentgyörgyHarta fault zone, Kapos-K: eastern segment of the Kapos-line) of the 3D geological-structural model projected to the base Quaternary horizon 


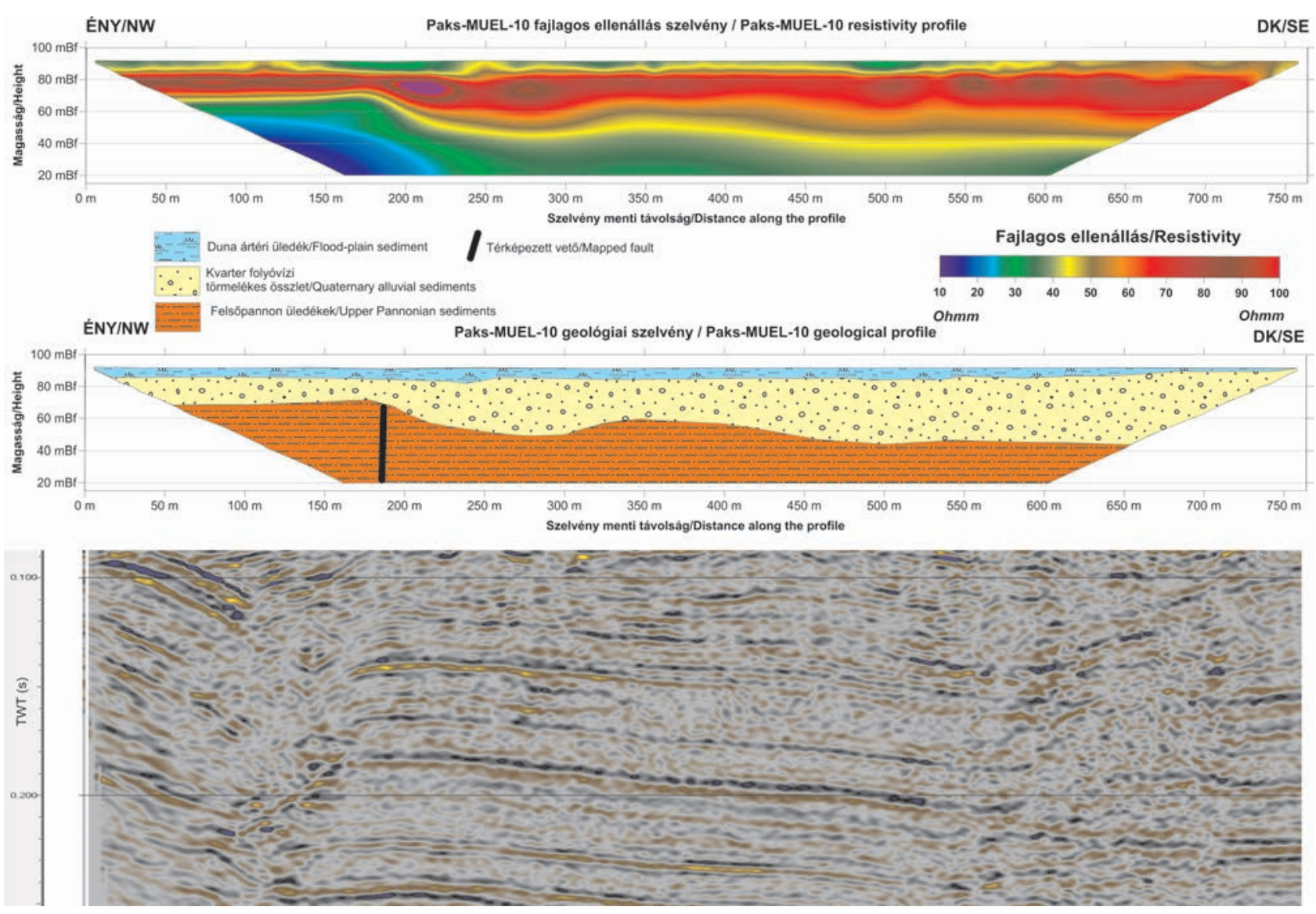

10. ábra. A Paks-MUEL-10 geoelektromos szelvény (fent) és értelmezése (középen). Alul: a MUEL-10 szelvénnyel lényegében megegyezỏ nyomvonalú (vö. 9. ábra), korábban mért nagyfelbontású Pa-13/94 szeizmikus szelvény a Paks-MUEL-10 szelvénnyel identikus részlete (TótH 2003 alapján). A szeizmikus szelvény horizontális léptéke megegyezik a bemutatott geoelektromos szelvényével

Figure 10. The geoelectric profile Paks-MUEL-10 (upper) and its geological interpretation (middle). Below: identical detail from the high-resolution $2 \mathrm{D}$ seismic line Pa13/94 (shot in 1994), having practically an identical trace with that of the geoelectric profile Paks-MUEL-10 (see Figure 9). The horizontal scale of the seismic profile is the same as that of the Paks-MUEL-10 geoelectric profile

györgy-Harta vetőzóna északi peremtörésének (9. ábra) feleltethető meg — megegyező helyen a MUEL-10 szelvényen a mélyebb, durvatörmelékes fluviális negyedidőszaki rétegekben markáns kivastagodás észlelhető. Ez értelmezhető (1) a vető kora-negyedidőszaki folyamatos aktivitásával és az ebból következő kismértékú folyamatos süllyedéssel, vagy (2) a késő-pannóniai vetômúködés következményeként a kvarter kezdetére kialakult olyan topográfiai különbséggel, amely a negyedidőszaki üledékképződést alapvetően preformálta. A kétféle értelmezés közül pusztán a MUEL-10 szelvény alapján nem lehet egyértelmúen állást foglalni, sôt ebben az esetben még a két módszer kombinációja is csak valószínúsítette, de nem tette egyértelmúvé a negyedidőszaki tektonikai aktivitás megítélését.

Ugyanakkor egyértelmú eredményre vezetett az előzóektől néhány 100m-re északkeletre a Geomega Kft. által 2016ban mért Pa-21-S jelű S-hullám sekélyreflexiós szeizmikus szelvény, illetve az annak nyomvonalán (valamint annak közelében) mélyült Pa-21- jelû vetôkutató sekélyfúrások, továbbá mindezek tapasztalatait is figyelembe vevő árkolás eredményei (9. ábra). A Pa-21-S szeizmikus szelvényen elsődlegesen értelmezett vetôkép (11. ábra) arra mutatott, hogy a vetődés a negyedidőszaki képződmények felszínközeli tartományát is érinthette. A szeizmikus szelvény alapján lemélyült $7 \mathrm{db}$ sekélyfúrás földtani adatai egyértelmúen igazolták a kvarter rétegsor bázisán települő Tengelici Vörösagyag tektonikus érintettségét a képződmény megléte/hiánya, továbbá a maganyagban talált vetőkarcok alapján (Ács et al. 2016: 2.1.3.2 fej., 245. ábra).

A Pa-21-S jelú reflexiós szeizmikus szelvény szerkezeti értelmezése alapján került sor a felszíntől számítva 3m mély kutatóárkok (Pa-21-I és -II) kialakítására a szelvény északnyugati részén (9. ábra). A $\mathrm{Pa}-21-\mathrm{S}$ szelvénnyel párhuzamos helyzetú, 80 m hosszú Pa-21-II árokban különböző szeizmotektonikus eredetû szerkezetek (szeizmitek, homokinjekciókkal kísért törések/hasadékok, tektonikus elmozdulási felületek; részletesen lásd Ács et al. 2016: 3.1.2.3 fejezet) tárultak fel felső-pleisztocénba sorolt futóhomokban. E szerkezetek pont ott jelentkeztek, ahol azt a Pa-21-S szelvényen értelmezett vetők felszíni folytatása jelezte. Ezek közül a leglátványosabb az árok közepén (43,7 m-nél) észlelt „,ölcsérmetszetû szerkezet”, és az ahhoz mindkét oldalon csatlakozó kis normálvetődések voltak (12. ábra). A szerkezet jellege és iránya, amely megegyezett a Dunaszentgyörgy- 

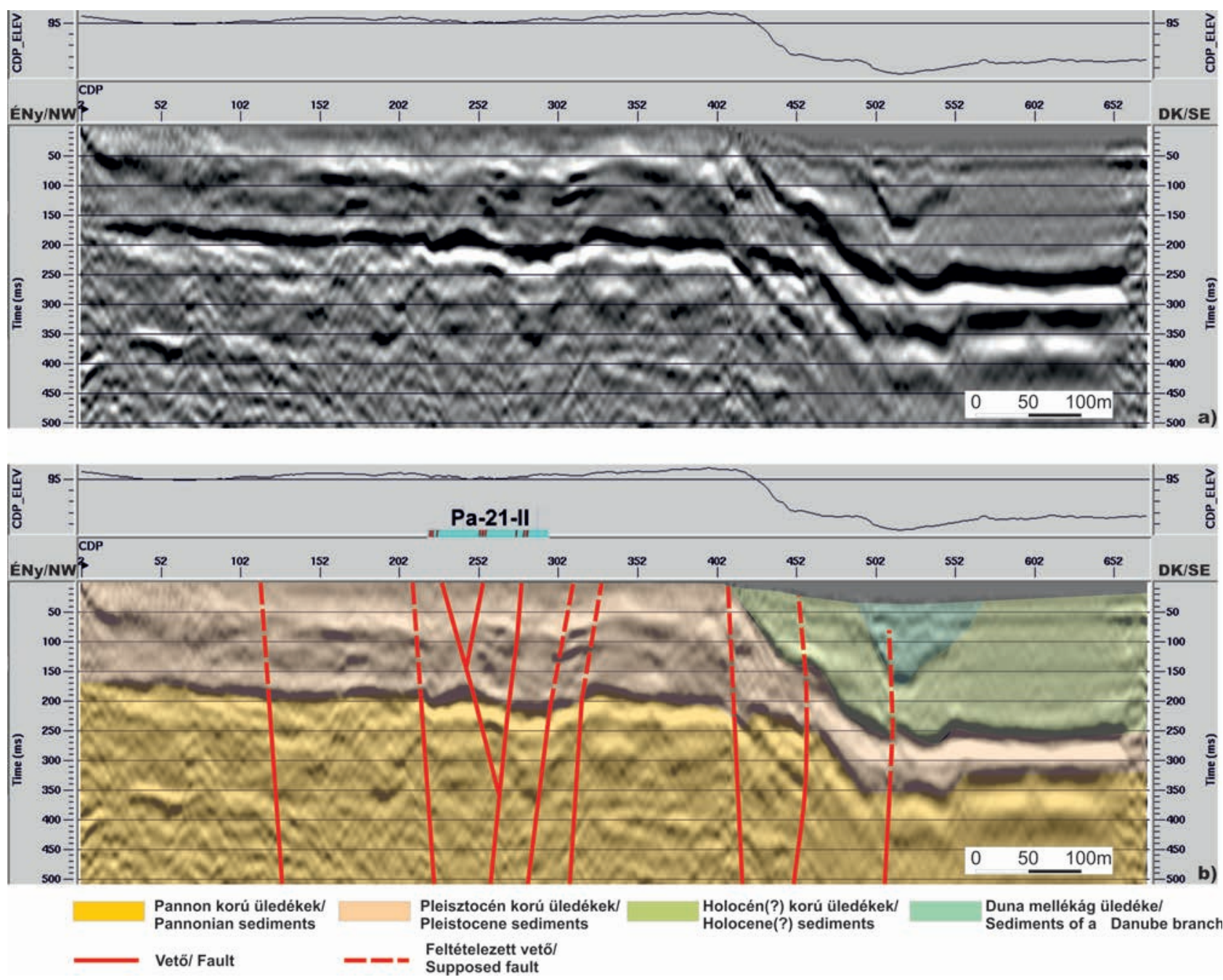

11. ábra. A Pa-21-S-Geomega S-hullám szeizmikus szelvény értelmezetlen (a) és értelmezett (b) változata. A szelvény helyét a 9. ábra mutatja. Az értelmezett változaton feltüntettük a $\mathrm{Pa}-21-\mathrm{II}$ árok helyét és az észlelt tektonikus szerkezeteket (piros vonalak)

Figure 11. The Pa-21-S-Geomega S-wave high-resolution 2D seismic profile without geological interpretation (a) and its interpreted version (b). For location see Figure 9. The location of the Pa-21-II trench and the observed tectonic features (red lines) are also shown on the interpreted version

Harta vető csapásával úgy értelmezhető, hogy az árkolás transztenziós negatív virágszerkezetet tárt fel, amely a szeizmikus adatrendszerben dokumentált, hasonló szerkezeti jellegú mélyvető felszínközeli megjelenését képezi. A szerkezet tanulmányozása azt is világossá tette, hogy az elmozdulás mértéke a vizsgált „kvázi-felszíni” szelvényben nagyon kicsi volt, nem haladta meg a néhány cm-t a szerkezet kialakulásakor. Ez azzal függhet össze, hogy az elvégzett, igen különböző léptékú vizsgálatok integrált tapasztalatai alapján a főbb mélytörések a felszín felé haladva egyre inkább szétágaznak, több ágra bomlanak (Ács et al. 2016: 247. ábra), és ezzel párhuzamosan a végbement teljes deformáció is egyre jobban szétoszlik az egyes ágak közt (ún. strain partitioning). Mindez az észlelt deformációs kép alapvető geometriai jellegzetességeinek skála-függetlenségét, azaz fraktál jellegét jelzi. A deformáció fraktál jellege nemcsak a tanulmányozott, különböző léptékû szelvényekben, hanem térképi vetületben is világosan jelentkezik: a Pa-21-II kutatóárokban dokumentált szeizmotektonikus szerkezetek sztereogramján ugyanazon fő irányok tükröződnek, mint a 2D és 3D szeizmikus adatrendszereken azonosított neotektonikus vetőrajzolaton (Ács et al. 2016: 418. ábra).

Az elvégzett OSL kormeghatározások szerint a Pa-21-II árokban feltárt futóhomok kora kb. 19-21 ezer év (THAMóBOZSÓ \& FÜRI 2016), ami egyben a megfigyelt deformáció maximális lehetséges korát adja. Mindezen adatok és megfigyelések a Dunaszentgyörgy-Harta vetőzóna késő-negyedidőszaki aktivitását egyértelmúen igazolták.

Fiatal negyedidőszaki szeizmotektonikai aktivitás nyomait lehetett továbbá kimutatni a pszeudo-3D vízi szeizmikus szelvényezés segítségével a 2. mérési blokkban. Ez ott helyezkedik el kb. 1540 fkm-nél, ahol a folyó medre alatt (azzal teljesen párhuzamosan) halad a DunaszentgyörgyHarta vetőzóna ÉK-DNy-i csapással (9. ábra). Ezen a területen kimutatható egy, a mai Dunát ferdén keresztező paleomeder (13. ábra), amelyet egy kb. 130 m széles és $4 \mathrm{~m}$ mély egykori folyóág hozott létre. A kimutatott paleomeder különlegességét az adja, hogy a felhagyott és feltöltött 

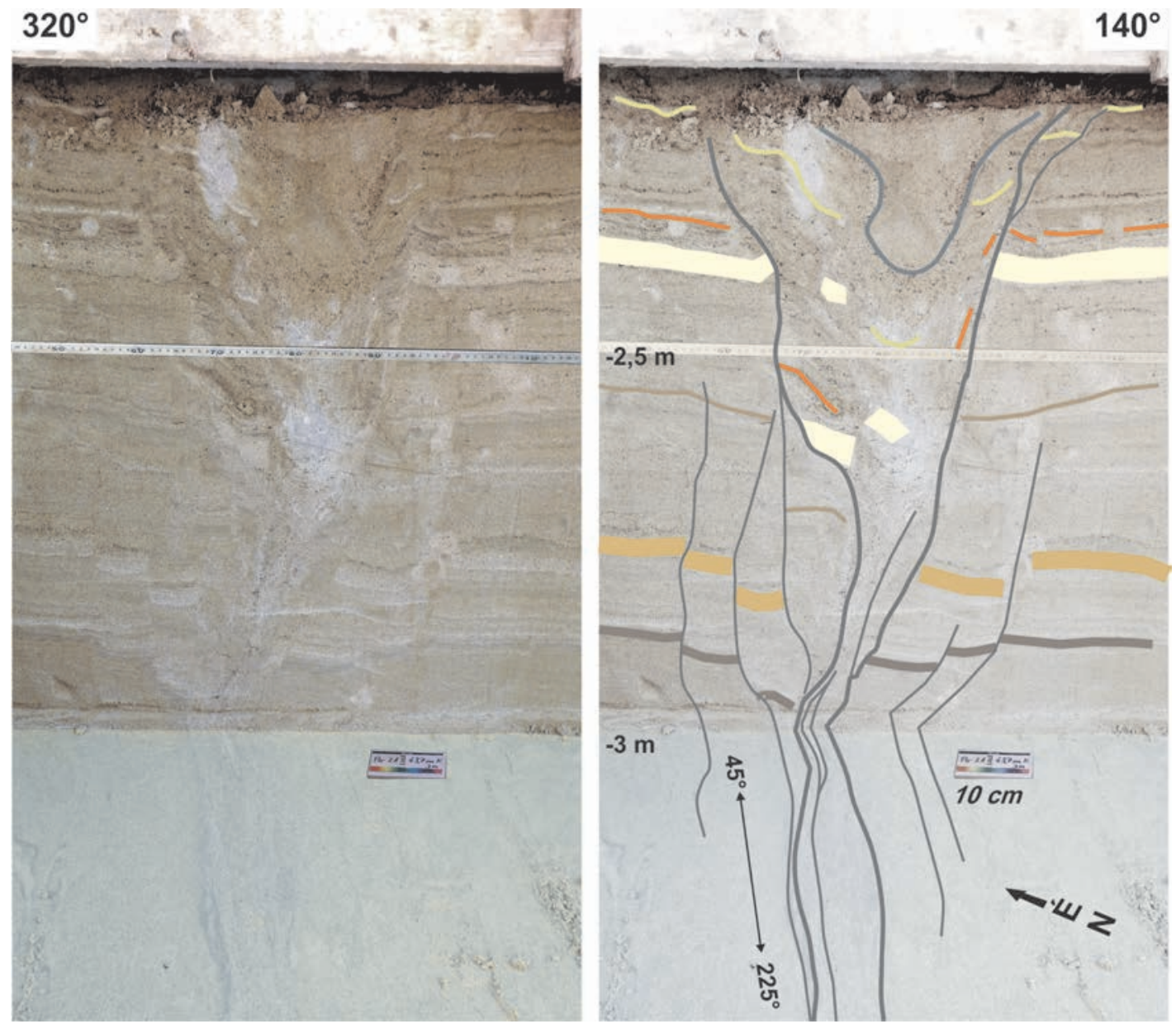

12. ábra. A Pa-21-S szelvény északnyugati részén kialakított kutatóárok (a helyszín a 9. ábrán) értelmezetlen részlete (K-i fal $43,7 \mathrm{~m}$ ): normálvetőkkel kísért, fölfelé kiszélesedő hasadék (bal oldalon). Jobb oldalon: értelmezett kép a marker-rétegek és vetők feltüntetésével Figure 12. Left: detail of the trench located at the north-western part of the Pa-21-S-Geomega S-wave high-resolution 2D seismic profile (for location see Figure 9) with an upward widening, funnel-like gash accompanied by small-scale normal faults (eastern wall $43.7 \mathrm{~m}$ ). Right: interpreted photo with marker beds and faults

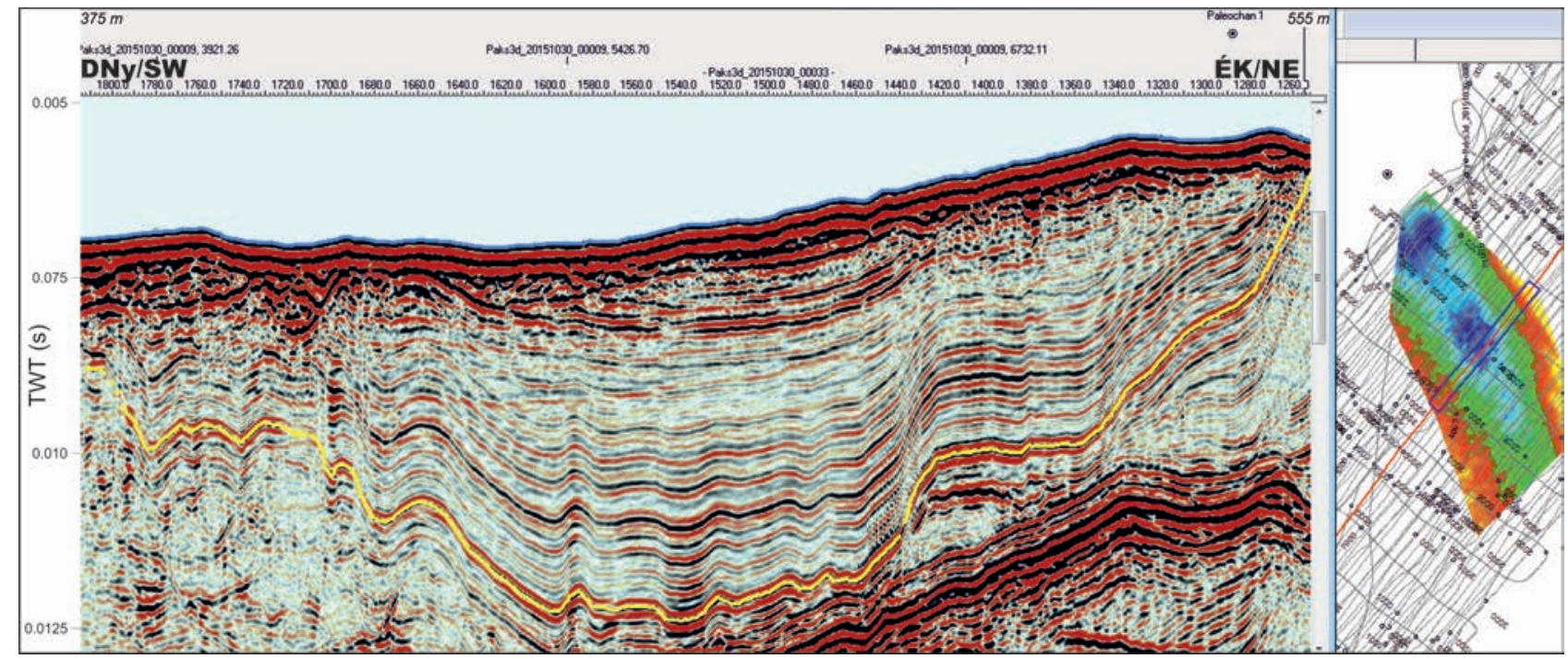

13. ábra. A pszeudo-3D vízi szeizmikus mérés 2. blokkjában leképezett egykori folyómeder, amelynek eredetileg vízszintesen települt üledékeit paleo-földrengés deformálta (szeizmit). A térképrészleten (jobb oldalon) látható medermorfológia a szelvényen sárga vonallal értelmezett horizont képe

Figure 13. Seismic image of an ancient river bed documented by the pseudo 3D water seismic survey (block 2, see Fig. 9). The deformation of the originally horizontally deposited beds was caused by a paleo-earthquake (seismite). The map of the right side shows the interpreted horizon (yellow) on the profile at the left 
medret (morotvát) kitöltố agyagos-iszapos üledékek jellegzetesen hullámosan deformált, gyưrődéses-csúszásos szerkezetet mutatnak, jóllehet eredetileg teljesen vízszintesen települtek. Ilyen szerkezeteket földrengéshullámok hatására bekövetkező vízkiszökés és kőzetváz-összeomlás okoz, emiatt szeizmitnek hívják. A deformált üledékösszlet felső részéből származó mintán végzett lumineszcens kormeghatározás szerint a kitöltố összlet kb. 11 ezer éves (Novothny 2016). A fenti koradat így a földrengés felső korhatárát jelezheti, tekintettel arra, hogy a paleomederkitöltés legfiatalabb rétegei már nem deformáltak a reflexiós képen (13. ábra). A pszeudo-3D szeizmikus adatrendszeren dokumentált szeizmit tehát egy olyan paleoföldrengés következtében deformált üledékszerkezetet mutat, amelyik a terület szeizmikus veszélyeztetettsége szempontjából számba veendő, ugyanakkor értelemszerúen nem szerepel a historikus események katalógusában.

\section{Diszkusszió}

\section{A kutatási terület szerkezeti viszonyai}

A 3D földtani-tektonikai modell vetőképét (6-7. ábrák) a korábbi kutatások alapján (BALLA 1994, illetve BADA et al. 2005; 2-3. ábrák), valamint a legfrissebb aljzattérképen (HAAs et al. 2010) ábrázolt szerkezeti viszonyokkal összevetve az alábbi következtetések adódnak:

1) A kutatási terület meghatározó szerkezeti elemei közül a „Kapos-vonal” és a Dunaszentgyörgy-Harta vetózóna helyzetét és kapcsolatát valamennyi feljebb hivatkozott térkép helyesen tüntette fel. E vetók közül a „Kapos-vonal” azonban sem geometriai (dőlésirány), sem neotektonikai aktivitás szempontjából nem alkot egységes szerkezeti elemet, hanem egy nyugati és egy keleti szegmensre bontható. Az egyes vetôszegmensek neotektonikus aktivitásában mutatkozó markáns különbséget BALLA (1994), BALLA et al. (1997) és DuDKo (1997) munkái is világosan jelezték.

2) Balla (1994) térképe a Kapos-vonalból számos kisebb jelentôségú, kiágazó törést jelzett (2. ábra). A vetôtérképezés eredményei alapján a bő két évtizede felvázolt szerkezeti kép alapvonásaiban és stílusában helytállónak bizonyult, ugyanakkor az egyedi kisebb vetôk tényleges geometriáját és kapcsolatrendszerét több helyen is pontosítottuk.

3) Az említett munkák azonban egyáltalán nem (HAAs et al. 2010), vagy csak hiányosan és pontatlanul (BALLA 1994, BADA et al. 2005) ábrázolták a Bonyhádi-medence ÉKDNy-i csapású mestertörését (Bonyhádi-törés) és az ahhoz kapcsolódó, hasonló irányú, széles vetôrendszert, jóllehet e vetőzóna ugyancsak a terület meghatározó szerkezeti elemei közé tartozik. Ez alapvetően a korábban felhasznált, viszonylag ritka $2 \mathrm{D}$ szeizmikus adatrendszerre vezethető vissza, amelyen a vetôkorrelációt csak számottevő bizonytalansággal lehetett elvégezni. A Bonyhádi-törés és kapcsolódó vetőrendszerének térképezése és ábrázolása tehát a kutatás egyik kiemelkedően fontos új eredménye.
5) A neotektonikusan aktív Bonyhádi vetôzóna regionális léptékben lényegében az ugyancsak markáns neotektonikus aktivitást mutató Dunaszentgyörgy-Harta vetőzóna DNy-i irányú folytatásának tekinthetô, amely délnyugat felé a Mecsek északi pikkelyzónájához kapcsolódik.

6) A Medina-Szedres-Tolna térségében feltüntetett kb. ÉNy-DK-i csapású szerkezeti elemek létezését (BADA et al. 2005; 3. ábra) a vetôtérképezés eredményei nem igazolták, hiszen e részterületet egyértelmúen a Bonyhádi vetőzóna ÉK-DNy-i csapású törései uralják. Kisebb jelentőségú ÉNy-DK-i csapású törések csupán néhány km-rel keletebbre, Dunaszentgyörgy térségében jelentkeznek ( 6 . $a ́ b r a$ ). Ez utóbbi területen a Fadd és Gerjen északi szomszédságában jelzett, a Kapos-vonallal kb. párhuzamos törések léte szintén nem nyert igazolást (vö. 3. és 6. ábrák).

7) Az aljzattérképpel (HAAS et al. 2010) való összevetésben további fontos új eredmény, hogy a Dunától keletre, Dunavecse, Kecel és Kiskunhalas közt feltüntetett, ÉÉNyDDK-i csapású haránttörés létezését az elvégzett térképezés nem igazolta. Ugyanez igaz a Tolna szomszédságában ábrázolt haránttörésre is. Ugyanakkor a térképezés számos további, kisebb jelentôségú ÉK-DNy-i csapású törés jelenlétét mutatta ki a kutatási területen, s így a korábbi szerkezeti képet számottevôen módosította.

8) A kutatások során lemélyült új szerkezetkutató és az archív fúrások földtani adatai (Ács et al. 2016: 200. ábra) arra mutatnak, hogy a Kapos-vonal a Mecsekialegység prekainozoos aljzatában a kristályos fekü vonatkozásában egyben fontos földtani határt is alkothat, legalábbis a vizsgált terület nyugati és középsô részén. Itt ugyanis a vonaltól északra a kristályos aljzatot variszkuszi metamorfózist szenvedett gneisz/csillámpala, míg attól délre variszkuszi (karbon) granitoidok építik fel (vö. 8. ábra). A mecseki mezozoikumhoz sorolható képződmények a vonal mindkét oldalán megjelennek az említett kristályos képződmények fedôjében. Ugyanakkor hangsúlyozzuk, hogy a rendelkezésre álló fúrási adatok még a kutatási területen belül is csak valószínúsítik, de nem teszik egyértelmúvé e modellt. A kutatási terület nyugati szomszédságának földtani adatai mindenesetre összhangban állnak e modellel. Kelet felé haladva azonban a Kapos-vonaltól északra is variszkuszi granitoidok építik fel a kristályos aljzatot (HAAs et al. 2010), az alföldi területen tehát a vonal már nem képez kiemelt jelentőségú földtani határt a kristályos aljzatban. A kétféle kristályos határa keleten valószínúleg a térképezett ÉK-DNy-i csapású törés egyike mentén húzódik ÉK felé. A prekainozoos aljzatra vonatkozó új fúrási információkat és a feljebb részletesen ismertetett szerkezeti eredményeket is figyelembe véve az aljzattérkép módosítása (Ács et al. 2016: 200. ábra) a kutatási területen megtörtént.

\section{Szerkezetalakulás}

Az alábbiakban röviden összefoglaljuk a kutatási terület szerkezetalakulásának fóbb eseményeit. Ennek során messzemenően támaszkodtunk a terület szúkebb és tágabb 
környezetének szerkezetfejlődését és annak geodinamikai kontextusát részletesen tárgyaló munkákra (WEIN 1961, 1967; HÁmor 1966; NÉMEd-VARGA 1977, 1983; WÉBER 1977; Horváth \& RoYden 1981; Horváth \& Cloetingh 1996; RoYden et al. 1982, 1983; BALla 1988; TARI 1992, 1994; FODOR et al. 1999; CSONTOS et al. 2002, 2005; BADA et al. 2002, 2005, 2007; LELKES-FELVÁRI \& FRANK 2006, KonRÁD \& SEBE 2010). A földtani fejlődéstörténet négy, egymástól jól elkülönülő főbb fejlődési szakaszra — premiocén, kora- és középső-miocén, késő-miocén (,pannóniai") és neotektonikus (pliocén-kvarter) szakaszra bontható, amelyeken belül nyolc jelentôsebb, részben további alfázisokra tagolódó deformációs fázis különíthető el.

1) A pre-miocén szakaszból két meghatározó jelentőségú orogén eseményt — a variszkuszi $\left(D_{1}\right)$ és eoalpi $\left(D_{2}\right)$ alapvetően kompresszív jellegú szerkezetalakulást — kell kiemelni, amelyek a pre-tercier aljzat mélyföldtani felépítését alapvetően megszabták. E szerkezetalakulási események részleteirôl azonban csak kevés közvetlen információ áll rendelkezésünkre a kutatási területen (1. Ács et al. 2016: 3.1.1.1 fej.). A fő kora-karbon, illetve kréta orogén események a tágabb környezetben általánosságban kb. ÉKDNy-i irányítottságú szerkezetek (palásság, pikkely- és takaróhatárok, redők; lásd pl. WEIN 1961, 1967; WÉBER 1977; NÉMEDI-VARGA 1983; KIRÁLY \& KoROKNAI 2004; MARos et al. 2004; HAAs et al. 2010) kialakulását eredményezték az aljzatban.

2a) A kréta orogenezist követően hosszú ideig nincs közvetlen információnk a fejlődéstörténetről, az intenzív lepusztulást szenvedett paleozoos és mezozoos aljzatképződmények felett markáns unkonformitással (lásd 1. jelû geológiai határfelület: $5 a-b$ ábrák) miocén képződmények települnek. A kora-miocén során intenzív riftesedés $\left(\mathrm{D}_{3}\right)$ ment végbe, feltehetôen kb. ÉNy-DK-i húzással és rá merőleges összenyomással jellemezhetô transztenziós/ eltolódásos feszültségtérben (vö. pl. HÁMOR 1966, BADA et al. 2002, Csontos et al. 2002). A létrejövő tektonikus árkokat a nagy reliefenergiájú környezet lepusztulásával keletkezett tavi-folyóvízi törmelékes üledékek töltötték fel (8. ábra; Ács et al. 2016: 3.1.1.4.2 fej.). A riftesedéshez kapcsolódó jelentős mértékú litoszféra-kivékonyodás és hőmérséklet-növekedés miatt a kontinentális üledékképződést élénk magmatizmus kísérte nagytömegú vulkáni kiömlési és explozív kőzet képződésével (8. ábra; Ács et al. 2016: 3.1.1.4.2 fej.).

2b) A kora-miocén fejlődési szakaszt részleteiben nem ismert kompresszív?/transzpresszív? esemény $\left(\mathrm{D}_{4}\right)$ zárta, amely az alsó-miocén vulkáni-törmelékes összlet deformációját idézte elő. Ide kapcsolódik a PAET-27 fúrásban dokumentált éles rátolódásos kontaktus a fedőt alkotó mezozoos kőzetek és a feküt képező alsó miocén üledékek közt (Ács et al. 2016: 16. ábra), továbbá a szeizmikus szelvényeken helyenként megfigyelhető szögdiszkordancia az alsó- és tengeri középső-miocén képződmények határán (2. jelú geológiai horizont: $5 a$ és $5 b$ ábrák).

2c) A középső-miocén korai fejlődési szakaszát általános süllyedés és kapcsolódó transzgresszió jellemezte, amely során a kezdeti partszegélyi üledékek mellett már pelágikus márgák is képződtek regionális elterjedésben. A süllyedés alapvetően a kora-miocén során létrejött vetők mentén történt kb. K-Ny-i húzással (és rá meróleges összenyomással) jellemezhető transztenziós (/tenziós?) (BADA et al. 2002, CsonTos et al. 2002) feszültségtérben $\left(D_{5}\right)$.

2d) A középső-miocén fejlődési szakasz végén a korábban létrejött tengeri kapcsolatok beszúkültek, majd megszúntek. Ekkor képződtek a brakkvízi szarmata képződmények. A szarmata legvégén és az azt követő időszakban emelkedés és lepusztulás zajlott, amely kiterjedt a teljes Pannon-medencére (HoRVÁTH et al. 2006, 2015). Sőt, a kb. É-D-i összenyomással és rá merőleges húzással jellemezhető transzpresszív/kompresszív feszültségtérben tektonikai inverzió zajlott. Regionális léptékben ennek következtében alakult ki a Pannon-medence üledékes összletének legmarkánsabb unkonformitása (3. jelú geológiai határfelület: $5 a$ és $5 b$ ábrák). Ez egyben a középső-miocén tengeri üledékes kőzetek felsô határa is, mert ettôl kezdődően alakult ki a későbbiekben fokozatosan kiédesedő Pannon-tó. A kutatási területen ezen szerkezetalakulás nyomait képviseli egyes miocén süllyedékek kisebb mértékű inverzója (Ács et al. 2016: 3.1.1.5.2 fej., BADA et al. 2005), és az ehhez kapcsolódó enyhe redőződés és feltolódások kialakulása $\left(\mathrm{D}_{6}\right)$.

3) A késő-miocén (,pannóniai”) fejlődési szakaszban a Pannon-tó kialakulását a világtengerektől immár elzárt medence gyors süllyedése alapozta meg. Ekkor egy tagolt topográfiájú, helyenként akár 1000 m mélységet elérő medencében főleg agyag- és mészmárga képződött, amelyik változó vastagságú lepelként fedte be a medence aljzatát, illetve a miocén képződményeket. Ennek felső határát jelzi a 4. geológiai határfelület ( $5 a$ és $5 b$ ábrák). A késő-miocénpliocén során intenzív, termikus eredetú általános süllyedés ment végbe (HORVÁTH \& ROYDEN 1981; ROYDEN et al. 1982, 1983), amelyre helyrôl helyre változó mértékú tektonikus eredetű süllyedés szuperponálódott. E fejlődési szakaszban összességében transztenziós jellegú feszültségtér jellemző kb. ÉNy-DK-i tágulással és erre meróleges összenyomással (FoDOR et al. 1999, BADA et al. 2002, CsONTOS et al. 2002). E feszültségrezsimben a $\sigma_{1}$ és $\sigma_{2}$ főfeszültségek valószínúleg közel álltak egymáshoz, s időben fel is cserélődhettek (feszültségtér permutáció), ami tenziós és transztenziós jellegú feszültségterek váltakozását idézhette elő. Ekkor az uralkodó ÉK-DNy-i csapású vetôk normál, illetve balos normál kinematikával múködhettek $\left(\mathrm{D}_{7}\right)$.

4) Az utolsó, neotektonikus fejlődési szakaszban a feszültségtér egyre inkább eltolódásos jellegúvé vált (Horváth \& Cloething 1996, Fodor et al. 1999, Csontos et al. 2002), amelyben a meghatározó ÉK-DNy-i és KÉKNyDNy-i csapású törések balos kinematikával reaktiválódtak $\left(\mathrm{D}_{8}\right)$. Tekintettel ezen szakasz tanulmányunk szempontjából kiemelkedő jelentôségére, az alábbiakban részletesen is ismertetjük a kinematikai rekonstrukciót és az ahhoz felhasznált mérési adatokat, továbbá röviden kitekintünk a vizsgált terület regionális tektonikai kontextusára is. 


\section{Neotektonikai szintézis}

Az új szerkezetkutató fúrásokban — a hidraulikus rétegrepesztéses módszer alkalmazásával — számos recens feszültség-meghatározást végeztek (ANDRÁssY 2015, 2016; DANKÓ 2015a-c, 2016), amelyek alapján a maximális vízszintes fơfeszültség $\left(\mathrm{S}_{\mathrm{H}}\right)$ átlagosan kb. 30-210 ${ }^{\circ}$ irányúnak adódott (LENKEY-BőGÉR et al. 2016). A meghatározott maximális vízszintes fő́feszültség iránya jó egyezést mutatott más módszerekkel (lyukfal kipergés — borehole breakout $[\mathrm{BO}]$, fúrás által indukált repedés - drilling induced fracture [DIF]) meghatározott fófeszültség irányokkal is (LENKEY-BŐGÉR et al. 2016). Továbbá ugyancsak összhangban van a kutatási területre korábbi mérések
(DöVÉNYI 1994) simító szúrésével és extrapolációjával kapott generalizált $S_{H}$ iránnyal (BADA et al. 2007). A feszültség-meghatározások adatait kombinálva a litosztatikai terhelésből adódó értékekkel $\left(S_{\mathrm{v}}\right)$ a recens feszültségtér eltolódásos jellege adódott, tehát $\sigma_{1}$ és $\sigma_{3}$ főfeszültségek a vízszintes síkban vannak, míg $\sigma_{2}$ függóleges helyzetú (LENKEY-BŐGÉR et al. 2016). Ezen adatok és a megelőző fejezetekben ismertetett eredmények alapján mutatjuk be a kutatási terület új neotektonikai szintézisét (14. ábra).

A feljebb jellemzett feszültségtérben a térképezett, uralkodóan ÉK-DNy-i, illetve KÉK-NyDNy-i csapású vetốk a fúrásokban balos(/balos normál) eltolódásként múködtek. Az eltolódásos jelleg jó összhangban van a szeizmikus szelvényeken megfigyelhetô szerkezeti jelle-

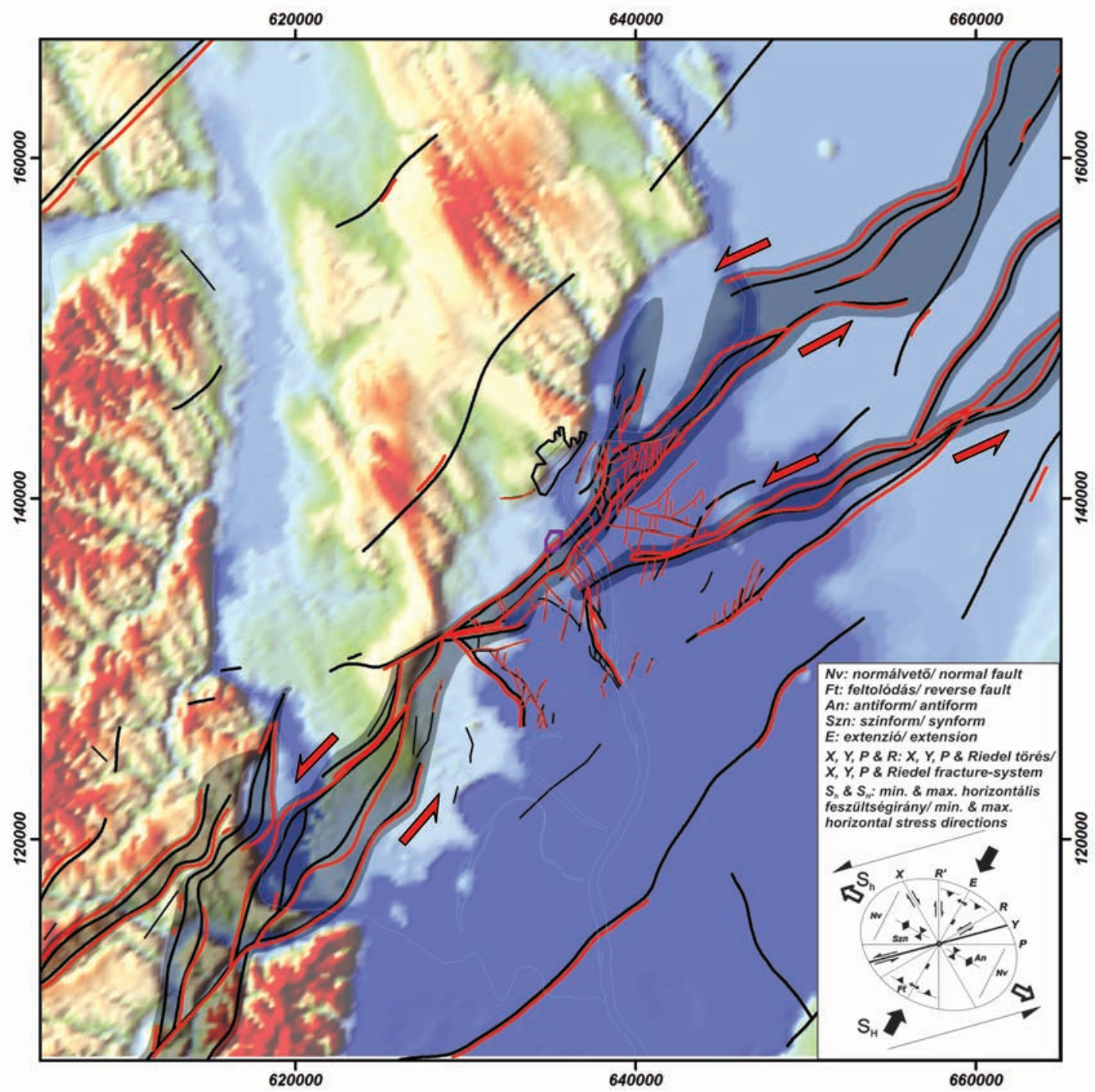

14. ábra. A kutatási terület meghatározó neotektonikus vetőzónáinak (szürke kiemelés) áttekintése (EOV koordinátarendszer) Piros vonalak: a pannon/kvarter határig, illetve annak közelébe felhatoló vetők; fekete vonalak: az Algyöi Formáció tetejét átmetsző vetők. Háttér: a kutatási terület digitális terepmodellje. Jobb alsó sarokban: az eltolódási zónákban kialakuló vetőkép elvi sémája (HANCOCK 1985) a regionális feszültségtér orientációjának figyelembevételével

Figure 14. Overview map on the major neotectonic fault zones (gray shading) of the study area (EOV coordinate system)

Red lines: faults reaching or approaching the Pannonian/Quaternary boundary; black lines: faults transecting the top-Algyö horizon. Background: the digital elevation model (DEM) of the study area. Lower right corner: theoretical arrangement of faults formed in a sinistral strike-slip zone (after HANCoCK 1985) regarding also the orientation of the regional stress field 
gekkel, hiszen mind a Kapos-vonal keleti szakasza, mind a Dunaszentgyörgy-Harta vetőzóna, illetve a Bonyhádi-medence vetôrendszere markáns virágszerkezetként jelentkezik. A térképi nézetben megfigyelhető fonatos, hajladozó geometria, melyhez számos kulisszás elrendeződésú segédtörés is csatlakozik (6., 7. és 14. ábrák), ugyancsak az eltolódásos kinematikát támasztja alá.

Az egyes vetők mentén, illetve vetőzónákban a 2D és 3D szeizmikus adatrendszerekben (koherencia-metszeteken) megfigyelt neotektonikus deformáció-intenzitás alapján (az adott törés/töréses öv szélessége és kapcsolódó törések számossága-geometriája, csapásmenti követhetőség és a vetô felső elvégződési szintjének csapásmenti konzisztenciája, észlelhetô elvetés mértéke) a kutatási terület összképében egyértelmúen meghatározó elemek a Kaposvonal keleti ága, a Dunaszentgyörgy-Harta vetôzóna és a Bonyhádi-medence vetôrendszere. Ezek együttesen egy regionális skálájú, nagyjából ÉK-DNy-i irányú balos eltolódásos övet körvonalaznak (14. ábra). A kutatási területen azonosított jelentôsebb, több-kevesebb neotektonikus aktivitást mutató vetők/vetôzónák többsége ezen meghatározó rendszerrel kb. párhuzamos irányú (pl. Mecsekaljaöv, Németkéri-magaslat északi és déli peremvetői, Tamásivetó), illetve ehhez a regionális rendszerhez kis szöggel csatlakozik. A csak ritkábban elóforduló, és kisebb jelentőségú ÉÉNy-DDK-i irányítottságú vető́k ebben a rendszerben ún. X-törésként (esetleg antitetikus Riedeltörésként) értelmezhetők, melyek mentén kisebb mértékú jobbos eltolódás ment végbe. Ez az értelmezés összhangban áll a szeizmikus szelvényeken észlelt tipikus virágszerkezetükkel.

A bemutatott eredmények alapján egyértelmú, hogy a neotektonikus szerkezetalakulás során a pannóniai rétegekben végbement markáns deformáció a fiatal negyedidőszaki (késô-pleisztocén végi) képződményeket ugyanolyan szerkezeti stílussal, de lényegesen kisebb intenzitással érintette. A kisebb látszólagos negyedidószaki intenzitásképhez mind a vetőrendszer felfelé szétágazó, fraktál jellege, mind a pannon képződményekben végbement nagyobb neotektonikus kumulatív deformáció hozzájárult. A Pa-21-S árok szerkezeti észlelései alapján valószínúnek látszik, hogy a negyedidőszaki képződmények deformációja nem egyetlen szeizmotektonikus eseményhez kapcsolódik, hanem az egyes vetôzónákban akár több fázisban is történhetett deformáció (nem feltétlenül csak vetőfelület menti elmozdulást jelentve, és nem feltétlenül egyidejúleg és megegyező intenzitással minden vetőzónában). A földtani értelemben igen fiatal, késő-negyedidőszaki aktivitást a kutatási területen tett számos további, e munkában nem részletezett neotektonikai megfigyelés is egyértelmúen alátámasztja (Ács et al. 2016: 426. ábra).

A negyedidőszaki tektonikai aktivitás kapcsán korábban Pogácsás et al. (1989) munkája világosan igazolta, hogy egyrészt szerkezeti kapcsolat van a Paks környékén kimutatott KÉK-NyDNy-i csapású vetôzóna és az általuk az Alföldön olajipari szeizmikus szelvényeken kimutatott Paks-Kiskőrös-Szolnok-Kisújszállás tektonikus öv között (azaz e tektonikus zóna képezi a Kapos-vonal keleti folytatását), másrészt ezen utóbbira fúrási adatok figyelembevételével pannóniai-kvarter aktivitást bizonyítottak az Alföldön. Ez utóbbira adtak további egyértelmú bizonyítékot DETZKY-LŐRINC $(1996,1997)$ munkái, valamint a vetózóna tiszai szakaszán mért vízi sekélyszeizmikus szelvény elemzési eredményei (TóTH \& HoRváTH 1999). Mindezen adatok kiváló összhangban vannak a kutatási területen a „Kaposvonal" keleti szegmensén megfigyelt jellegzetességekkel, s a Kapos-vonal Dunától keletre eső teljes szakaszának igen fiatal neotektonikai aktivitását igazolják.

A felvázolt neotektonikai szintézis kapcsán mutatunk rá végül arra is, hogy az ifj. Lóczy (1939) térképén látható szerkezeti kép abban a vonatkozásban lényegében helytálló, hogy a vizsgált területen valóban a Kapos-K, a DunaszentgyörgyHarta vetôzóna, valamint a Bonyhádi vetőzóna alkotják a vizsgált terület legalapvetốbb neotektonikusan aktív töréseit. Ugyanakkor a délnyugati irányban a Mecsek északi pikkelyzónájába csatlakozó Bonyhádi vetőzóna — ifj. Lóczy (1939) térképével szemben — nem tekinthetô a Kapos-vonal nyugati folytatásának (vö. l. ábra).

\section{Összefoglalás}

A kutatás során lemért új 3D adattömb és korábbi 2D szeizmikus szelvények, továbbá az új szerkezetkutató és archív fúrások integrált értelmezésével a kutatási területről új, földtanilag és geometriailag egyaránt konzisztens új 3D földtani-tektonikai modellt hoztunk létre, amelynek eredményei a korábban kialakult földtani-tektonikai képet részben pontosították, részben pedig számottevő változásokat is hoztak abban. A modell a vizsgált terület földtani felépítésének alapvonásait szem elôtt tartva öt alapvető jelentőségú földtani horizont (prekainozoos aljzattetô, kontinentális törmelékes/vulkáni miocén tető, tengeri középsômiocén tető, Endrőd-tetô, Algyő-tetô) és az értelmezett vetốk célorientáltan egyszerúsített téradatrendszerét tartalmazza.

Mélyföldtani szempontból fontos új eredmény a kristályos és mezozoos aljzatképződmények szerkezeti, elterjedési és kifejlődési viszonyainak felülvizsgálata és pontosítása a lemélyült szerkezetkutató fúrások és a szeizmikus adatrendszer integrált értelmezése alapján. Ugyancsak kiemelkedő jelentőségú a markáns kora-miocén riftesedés kimutatása, amelyet a létrejött, helyenként akár $2 \mathrm{~km}$ mélységú süllyedékekben intenzív, többfázisú mészalkáli vulkáni múködés, illetve egyidejú kontinentális üledékképződés kísért. Mindez tágabb kontextusban a Pannonmedence korábban kevésbé ismert kora-miocén kialakulási szakaszának jelentőségre hívja fel a figyelmet.

A kutatási terület szerkezeti képét uralkodóan ÉK-DNy-i csapású vetőrendszerek határozzák meg. Regionális léptékben kiemelkedó jelentôségú elem a KÉK-NyDNy-i csapású „Kapos-vonal”, amely két eltérő dőlésú, és neotektonikus aktivitásban is markánsan különböző keleti és nyugati szakaszra osztható, tehát geometriai-szerkezeti 
értelemben egységes Kapos-vonal nem létezik. A fentiekre kb. merőleges ÉÉNy-DDK-i csapású, szerkezetileg kevésbé jelentős törések fő́ként a Kapos-vonaltól délre jelentkeznek.

A terület meghatározó vetőzónáinak a KÉK-NyDNy-i csapású „Kapos-vonal”, továbbá az ÉK-DNy-i csapású Dunaszentgyörgy-Harta és az ezen kutatás során elôször részletesen térképezett Bonyhádi vetőzóna tekinthető, amelyeket mind meredek dőlés $\left(\geq 60-70^{\circ}\right)$ jellemez. Ez utóbbi délnyugati irányban a Mecsek északi pikkelyzónájához csatlakozik. E vetőzónák - a Kapos-vonal nyugati szegmensétől eltekintve — mind markáns neotektonikus aktivitást mutatnak, és regionális léptékben egy alapvetően ÉK-DNy-i és KÉK-NyDNy-i csapású elemekből felépülő, széles nyírási zónát körvonalaznak, amely a neotektonikus fázisban balos eltolódásként múködött. Ezt igazolja az egyes vetőzónákban megfigyelt tipikus ,virágszerkezetet” mutató belsô struktúra, továbbá a térképi nézetben megfigyelt kapcsolódó másodlagos formaelemek (Riedeltörések) is. Az említett vetőzónák a Pannon-medence kialakulását inicializáló kora/középső-miocén tektonikai elemek felújulásaiként jöttek létre.

A kialakított 3D modell eredményeinek figyelembevételével és a fokozatos megismerés elve alapján telepített nagyfelbontású 2D és pszeudo-3D sekélygeofizikai vizsgálatok, valamint az ezek eredményei alapján kijelölt árkolás és sekélyfúrások adatai bizonyították a Dunaszentgyörgy-Harta vetőzóna negyedidőszaki, sôt az árkolás eredményei szerint késő-negyedidőszaki aktivitását, hiszen az árokban feltárt késô-pleisztocén végi futóhomok tektonikus eredetû́ deformációja — többek közt transztenziós eredetú virágszerkezet dokumentálásával — egyértelmúen igazolódott.
A fiatal negyedidőszaki aktivitást a kutatási területen számos további korábbi, illetve a jelen kutatáshoz kapcsolódó, de e tanulmányban nem részletezett neotektonikai megfigyelés is alátámasztja. Mindezen eredmények alapján a terület negyedidőszaki tektonikai aktivitásáról szóló, több évtizedes tudományos vita — egyértelmú eredménnyel — lezártnak tekinthetô. A cikkünkben bemutatott eredmények a szakirodalomban a Kapos-vonal keleti szakaszáról (DunaTisza köze és Tiszántúl) közölt tektonikai adatokkal és értelmezéssel teljes összhangban állnak.

\section{Köszönetnyilvánítás}

A Kapos-vonal szerkezeti vizsgálatában elért új eredményekhez alapvetően járult hozzá a Paksi Atomerőmú telephelyének Földtani Kutatási Programja. A Szerzók ezúton fejezik ki köszönetüket a Földtani Kutatási Program beruházójának, a Paks II Zrt.-nek, valamint kivitelezőjének, a Mecsekérc Zrt.-nek a kutatási program során nyújtott támogatásukért. Köszönjük EcK József és HoRváTH Miklós Ferenc projektvezető igazgatók, valamint CsICSÁK József projektigazgató és BARABÁS András projektvezetô segítségét. Külön köszönet illeti Dr. KATONA Tamást évtizedeken átnyúló, a terület földtani megismerését mindig támogató segítségéért. Dr. Palotai Mártonnak és egy ismeretlen Lektornak az alapos lektori véleményekért és a konstruktív kritikai megjegyzésekért tartozunk köszönettel. Dr. SzTANó Orsolya főszerkesztő asszonynak ezúton is köszönjük a kézirat javítását elősegítő hasznos tanácsait és megjegyzéseit.

\section{Irodalom — References}

ANDRÁSSY M. (szerk.) 2015: Gyorsjelentés a PAET-26 jelú fúrásban végzett hidrorepesztéses vizsgálatokról. — MÁ/PA2-15-HI-06, Golder Kft.

ANDRÁSSY M. (szerk.) 2016: Gyorsjelentés a PAET-27 jelú fúrásban végzett hidrorepesztéses vizsgálatokról. — MÁ/PA2-16-HI-08, Golder Kft.

Ács T., Andrássy M., Balogh Z., Barabás A., Barna I., Bereczki L., Csillag G., Dankó Gy., Farkas M. P., Filipszki P., Geiger J., Gondár K., Gondárné Sőregi K., Grenerczy Gy., Gúthy T., Győri E., Halmai Á., Hámori Z., Kádi Z., Koloszár L., KoroKnai B., Korpai F., Kovács A. Cs., Kozma Zs., KönczÖl N-nÉ, Krupa Á., Kudó I., Mahler A., Maros Gy., Marótiné KisZely M., Máthé Z., Móczár B., Mónus P., Nagy R., Németh V., RátKai O., RátKy É., SAid D., Síkhegyi F., SứRú P., TaKács E., TalPas L., Tompai Z., WÁGENHOFFer A., Weiser L., WóRUM G. \& ZACHAR J. 2016: Földtani Kutatási Program Zárójelentése. — Paks II telephelyengedélyének megszerzéséhez szükséges földtani kutatás végrehajtása. Feladatkód: (1.3.25.), I/VI. kötet, 2016. szeptember 20. 785 p.

Bada G., SzAfián P., Windhofer G. 2002: A tervezett Kis és Közepes Aktivitású Radioaktív Hulladéktároló (Üveghuta, Bátaapáti) Környezetének Szeizmotektonikai viszonyai. — Kézirat, Geomega Kft., 126 p.

Bada G., Bus Z., Gribovszki K., Horváth F., Magyari Á., Mónus P., Szeidovitz Gy., Tímár G., Tóth T., Wéber Z. \& Wórum G. 2005 : A tíz éve folyó mikroszeizmikus monitorozás eredményeinek szeizmológiai értékelése és a neotektonikai modell megújítása. A Paksi Atomerőmú tervezett üzemidő-hosszabbítására vonatkozó Részletes Környezeti Hatástanulmányt (RKHT) előkészítő földtani, szeizmotektonikai és geotechnikai értékelés. II. kötet. — Kutatási jelentés az ETV-ERŐTERV Rt. részére, Georisk Kft. és Geomega Kft., Budapest, 219 p.

Bada, G., Horváth, F., Dövényi, P., Szafián, P., Windhoffer, G. \& Cloetingh S. 2007: Present-day stress field and tectonic inversion in the Pannonian basin. - Global Planetary Change 58, 165-180.

BALLA, Z. 1988: On the origin of the structural pattern of Hungary. — Acta Geologica Hungarica 31, 53-63.

BALla Z. 1994: A Paksi Atomerômú körzetének földtani felépítése. —Összesítő tanulmány, 6. kötet. Kézirat, PAE jelentéstár, Paks, 99 p.

BALLA Z. 1999: Van-e bizonyíték negyedidőszaki tektonizmusra Paks környékén? („A paksi atomerőmú földrengésbiztonsága” kötet megjelenése kapcsán). — Földtani Közlöny 129, 97-107. 
Balla Z., Marosi S., Scheuer Gy., Scweitzer F. \& Szeidovitz Gy. 1993: A Paksi Atomerőmú földrengéskockázatával kapcsolatos szerkezeti és geomorfológiai vizsgálatok. — Földrajzi Értesító 42, 111-140.

Balla Z., DudKo A. \& Maros Gy. 1997: Paks környékének mélyszerkezete és neotektonikája. — In: Marosi S. \& MeSKó A. (szerk.): A Paksi Atomerômú földrengésbiztonsága. Akadémiai Kiadó, Budapest, 33-59.

Balogh K., Horusitzky F., Kretzoi M., Noszky J., Rónai A. \& Szentes F. 1958: Magyarázó Magyarország 1:300 000-es földtani térképéhez. - A Magyar Állami Földtani Intézet kiadványa, Múszaki Kiadó, Budapest, 115 p.

Csontos, L., Benkovics, L., Bergerat, F., Mansy, J-L., Wórum, G. 2002: Tertiary deformation history from seismic section study and fault analysis in a former European Tethyan margin (the Mecsek-Villány area, SW Hungary) — Tectonophysics 357, 81-102.

Csontos, L., Magyari, Á., Van Vliet-Lanoe, B. \& Musitz, B. 2005: Neotectonics of the Somogy hills (Part II): Evidence from seismic sections. - Tectonophysics 410, 63-80.

CsOMOR D. \& Kiss Z. 1962: Magyarország szeizmicitása (II. rész). — Geofizikai Közlemények 11, 51-57.

DANKó Gy. (szerk.) 2015a: Gyorsjelentés a PAET-29 jelú fúrásban végzett hidrorepesztéses vizsgálatokról (3.1.2.). — MÁ/PA2-15-HI05, Golder Kft.

DANKó Gy. (szerk.) 2015b: Gyorsjelentés a PAET-34 jelü fúrásban végzett hidrorepesztéses vizsgálatokról. — MÁ/PA2-15-HI-08, Golder Kft.

DANKÓ Gy. (szerk.) 2015c: Gyorsjelentés a PAET-34 jelú fúrásban végzett hidrorepesztéses vizsgálatok 2. kampányáról. —MÁ/PA2-15HI-09, Golder Kft.

DANKÓ Gy. (szerk.) 2016: Gyorsjelentés a PAET-27 jelü fúrásban végzett hidrorepesztéses vizsgálatok 2. kampányáról. — MÁ/PA2-16HI-09, Golder Kft.

DETZKYNÉ LőRINCZ K. 1996: Feszültségtér történet meghatározása szeizmikus szelvényeken azonosított többfázisú tektonizmus alapján, Szolnoki flis öv nyugati peremén. - Magyar Geofizika 37, 228-246.

DETZKYNÉ LŐRINCZ K. 1997: Részletes tektonikai vizsgálatok a Szolnoki Flis Öv nyugati peremén szeizmikus és mélyfúrási adatok alapján. - Kandidátusi értekezés, MTA Könyvtár, Budapest.

DöVÉNYI P. 1994: Geofizikai vizsgálatok a Pannon-medence litoszféra fejlödésének megértéséhez. — Kandidátusi értekezés. ELTE Geofizikai Tsz., Budapest, 120 p.

DudKo, A. 1997: Neogene tectonics of the Mezőföld. — Annual Report of the Geological Institute of Hungary 1996/II, $213-223$.

ERDÉLYI M. 1961: Külső-Somogy vízföldtana. — Hidrológiai Közlöny 41, 445-458.

ERDÉlYI M. 1962: Külső-Somogy vízföldtana. — Hidrológiai Közlöny 42, 56-64.

Fodor, L., Csontos, L., BADA, G., Győrfi, I. \& Benkovics, L. 1999: Tertiary tectonic evolution of the Pannonian basin system and neighbouring orogens: a new synthesis of paleostress data. In: Durand, B., Jolivet, L., Horváth, F. \& Seranne, M. (eds): The Mediterranean Basins: Tertiary Extension within the Alpine orogen. _ Geological Society, London, Special Publication 156, $295-334$.

HaAs J., Budai T., Csontos L., Fodor L. \& KonRÁD Gy. 2010: Magyarország prekainozoos földtani térképe, 1:500 000 [Pre-Cenozoic geological map of Hungary, 1:500 000]. — A Magyar Állami Földtani Intézet kiadványa.

HANCOCK, P. L. 1985: Brittle microtectonics: principles and practice. - Journal of Structural Geology 7, 437-457.

HARANGi Sz. 2016a: A Pa2-13/2016 Kutatás fejlesztési megállapodás keretében végzett a PAET-29 sz. mélyfúrás által feltárt vulkáni képzódményekból vett közetminták cirkon U/Pb geokronológiai vizsgálati eredményei. — Laboratóriumi jegyzőkönyv, MTA ELTE Vulkanológiai Kutatócsoport, 1-16.

HARANGI Sz. 2016b: A Pa2-13/2016 Kutatás fejlesztési megállapodás keretében végzett a PAET-34 sz. mélyfúrás által feltárt vulkáni képződményekból vett közetminták cirkon U/Pb geokronológiai vizsgálati eredményei. — Laboratóriumi jegyzókönyv, MTA ELTE Vulkanológiai Kutatócsoport, 1-24.

HÁMOR G. 1966: Újabb adatok a Mecsek hegység szerkezetföldtani felépítéséhez. — A Magyar Állami Földtani Intézet Évi jelentése az 1964. évröl, 193-206.

Horváth, F. \& Royden, L. 1981: Mechanism for the Formation of the Intra-Carpathian Basins: a Review. —Earth Evolution Science 3, 307-316.

Horváth, F. \& Cloetingh, S. 1996: Stress-induced late-stage subsidence anomalies in the Pannonian basin. Tectonophysics 266, 287-300.

Horváth F., Csontos L., Erdélyi M., Ferencz Cs., Gábris Gy., Hevesi A. \& Síkhegyi F. 1990: Paks környezetének neotektonikája. — Kézirat, PAE jelentéstár, Paks, 71 p.

Horváth F., Csontos L., Dövényi P., Wéber Z., Drahos D., NAgymarosy A., SZÉKely B., Timár G., Győri E., SZABó A., VÁrkonyi L., Cserny T., Czeller I., Gombos Cs., Remete L., SAmu L. \& Buntebarth G. 1993: Paks környezetének szerkezeti viszonyai és nagytektonikai helyzete az újabb szeizmikus szelvények és más földtani geofizikai adatok komplex kiértékelése alapján. — Kézirat, PAE jelentéstár, Paks, 92 p.

Horváth, F., Bada, G., Szafián, P., Tari, G., ÁdÁM, A. \& Cloetingh, S., 2006: Formation and deformation of the Pannonian basin: Constraints from observational data. — In: Gee, D. G. \& STEPHENson, R.A. (eds): European Lithosphere Dynamics. — Geological Society, London, Memoirs 32, 191-206.

Horváth F., Musitz, B., Balázs, A., VéGh, A., Uhrin, A., NÁdor, A., Koroknai B., PAP, N., Tóth, T. \& Wórum, G. 2015: Evolution of the Pannonian basin and its geothermal resources. - Geothermics 53, 328-352.

KIRÁLY, E. \& KoROKNAI, B. 2004: The magmatic and metamorphic evolution of the northeastern part of the Mórágy Block (A Mórágyirög ÉK-i részének magmás és metamorf fejlődéstörténete). — MÁFI Évi Jelentése 2003-ról, 299-318.

KonRÁD Gy. \& SEBE K. 2010: Fiatal tektonikai jelenségek új észlelései a Nyugati-Mecsekben és környezetében. — Földtani Közlöny 140, $135-162$.

Kovács A. Cs., Redlerné Dr. TÁTRAi M. \& TAKÁCs E. 2016: Nagyfelbontású 2D szárazföldi reflexiós szeizmikus szelvényezés. — Jelentés. MFGI, $36 \mathrm{p}$. 
KőRöSsY L. 1963: Magyarország medenceterületeinek összehasonlító földtani szerkezete. — Földtani Közlöny 93, $153-172$.

Kudó I., Horváth F. \& Wórum G. 2016: Nagyfelbontású 2D szárazföldi geoelektromos szelvényezés. — Jelentés. Paks II telephelyengedélyének megszerzéséhez szükséges földtani kutatás végrehajtása. MÁ/PA2-15-GF/09, Geomega Kft., 34 p.

LELKES-FELVÁRI, GY. \& FrANK, W. 2006: Geochronology of the metamorphic basement, Transdanubian part of the Tisza Mega-Unit. — Acta Geologica Hungarica 49, 189-206.

LENKEY-BôGÉR Á., KovÁCS L. \& MÉSZÁROs E. 2016: Különbözô módszerekkel végzett in situ mérésekból és szakirodalomkutatásból származó primer feszültségadatok összefoglaló értékelése (Feladatkód: 1.3.14). — Kőmérő Kft., 88 p.

Lóczy L. Ifj. 1939: A magyar medencerendszer geomorfológiája, különös tekintettel a petróleumkutatásra. — Földrajzi Közlemények 67, 384-398.

MaGYAR I. 2010: A Pannon-medence ösföldrajza és környezeti viszonyai a késó miocénban. — Geolitera, Szeged, 1-140.

Magyar, I., Sztanó, O., Sebe, K., Katona, L., Csoma, V., Görög, Á., Tóth, E., Šujan, M., Braucher, R., RuszKiczay-Rüdiger, Zs., Koroknai, B., Wórum, G., SAnt, K., Kelder, N. \& Krijgsman, W. 2019: Towards a high-resolution chronostratigraphy and geochronology for the Pannonian Stage: Significance of the Paks cores (Central Pannonian Basin). — Földtani Közlöny (jelen kötet).

Maros, Gy., Koroknai, B., Palotás, K., Fodor, L., Dudko, A., Forián-Szabó, M., Zilahi-Sebess, L. \& BÁn-Győry, E. 2004: Tectonic analysis and structural evolution of the north-eastern Mórágy Block (A Mórágyi-rög ÉK-i részének tektonikai elemzése és szerkezetalakulása). — MÁFI Évi Jelentése 2003-ról, 371-394.

Marosi S. \& Schweitzer F. 1997: Geomorfológiai vizsgálatok Paks környékén. — In: Marosi S. \& Meskó A. (szerk.): A paksi atomerômú földrengésbiztonsága. Akadémiai kiadó, Budapest, 153-175.

NÉmedi VARGA Z. 1977: A Kapos-vonal. — Földtani Közlöny 107, 313-328.

NÉMEDI VARGA Z. 1983: A Mecsek hegység szerkezetalakulása az alpi hegységképződési ciklusban (in Hungarian with English abstract: Structural history of the Mecsek mountains in the Alpine orogenic cycle). — A Magyar Állami Földtani Intézet Évi Jelentése 1981ról, 467-484.

Novothny Á. 2016: Lumineszcens kormeghatározás a paksi telephelyen létesítendő új atomerômúvi blokkok földtani kutatási programjához. — Kézirat, ELTE. Budapest, 38 p.

OveArup \& Partners International 1996: PHARE Regional Programme Nuclear Safety. Project no. 4.2.1 VVER 440-213 Seismic Hazard Reevaluation. — Final Report, Summary, Task 7. Paks.

PogÁcsÁs Gy., LAKATOs L., BARVITZ A., VAKARCs G. \& FARKAs Cs. 1989: Pliocén-quarter oldaleltolódások a Nagyalföldön. - Általános Földtani Szemle 24, 149-169.

PosGAY K. 1967: A magyarországi földmágneses hatók áttekintő vizsgálata. — Geofizikai Közlemények 16, 23-118.

Ráner G., Szabó Z., Bucsi Szabó L., D. Lőrincz K., Fejes I., Gulyás Á., Gúthy T., KovácsvÖlgyi S., Madarasi L., Nemesi L., Pancsics Z., Pattantyús-Á. M., Redlerné TÁtrai M., Stickel J., Tóth T., Tőrös E. \& Varga G. 1997: Geofizikai kutatások Paks térségében. — In: MARosi S. \& Meskó A. (szerk.): A paksi atomerómúföldrengésbiztonsága. Akadémiai kiadó, Budapest, 61-94.

RónAi A. 1973: A negyedkori kéregmozgások térképe Magyarországon. — MTA X. Osztály Közleményei 7, $214-243$.

Royden, L. H., Horváth, F., \& BurChFiel, B. C. 1982: Transform faulting, extension and subduction in the Carpathian-Pannonian region. - Geological Society of America Bulletin 73, 717-725.

Royden, L. H., Horváth, F., Nagymarosy, A. \& Stegena, F. 1983: Evolution of the Pannonian Basin System. 2. Subsidence and thermal history. - Tectonics 2, 91-137.

SCHEFFER V. 1960: A magyar „közbülső tömeg” kérdéséhez. — Geofizikai Közlemények 9, 55-68.

SCHEFFER V. \& KÁNTÁs K. 1949: A Dunántúl regionális geofizikája. — Földtani Közlöny 79, 327-360.

SZEPESHÁZY K. 1975: Az Északkeleti-Kárpátok felépítésének és a kárpáti térségben való nagyszerkezeti helyzetének vázlata. — Általános Földtani Szemle 8, 25-29.

TARI, G. 1992: Late Neogene transpression in the Northern Imbricates zone, Mecsek Mountains, Hungary. — Annales Universitatis Scientiarum Budapestinensis de Rolando Eötvös Nominatae. Sectio geologica 29, 165-187.

TARI, G. 1994: Alpine Tectonics of the Pannonian basin. — PhD Thesis, Rice University, Texas, USA. 501 p.

THAMÓnÉ Bozsó E. \& FüRi J. 2016: OSL kormeghatározási eredmények. Paks környéki minták V. — Magyar Földtani és Geofizikai Intézet, $13 \mathrm{p}$.

Tóth T. \& Horvát, F. 1997: Neotektonikus vizsgálatok nagyfelbontású szeizmikus szelvényezéssel. — In: Marosi S. \& Meskó A. (szerk.): A paksi atomerômú földrengésbiztonsága. Akadémiai kiadó, Budapest, 123-152.

TóTH T. \& HoRvÁTH F. 1999: Van bizonyíték a negyedidőszaki tektonizmusra Paks környékén! — Földtani Közlöny 129, 109-124.

Tóтн T. 2003: Folyóvízi szeizmikus mérések. — Doktori (PhD) értekezés. ELTE Geofizikai Tanszék, Budapest, 141 p.

Tótн T. 2016: Felszíni geofizikai kutatások értékelójelentése. — Feladatkód: 1.3.10. 2016. június 16., 109 p.

WEIN Gy. 1961: A szerkezetalakulás mozzanatai és jellegei a Keleti-Mecsekben (Phasen und Beschaffenheit der tektonischen Ausbildung im östlichen Mecsek-Gebirge). — A Magyar Állami Földtani Intézet Évkönyve 49, 759-768 (945-956).

WeIN GY. 1967: A Délkelet-Dunántúl hegységszerkezete. — Földtani Közlöny 97, 371-395.

WÉBER B. 1977: Nagyszerkezeti szelvényvázlat a Ny-Mecsekból. — Földtani Közlöny 107, $27-37$.

Wórum G., Biró A., KÁdi Z., KoroKnAI B., KovÁcs G. \& Visnovitz F. 2015: Értékeló jelentés a 3D szeizmikus kutatás eredményeiról (1.3.9.). — MÁ/PA2-15-SZ/08 01, Geomega Kft., 48 p.

Wórum G., Biró A., Hámori Z., Koroknai Zs., SzÁntó É. \& Tóth T. 2016: Pszeudo-3D vízi szeizmikus mérések. — Zárójelentés. MÁ/PA2-15-SZ/14. Geomega Kft., 39 p.

Kézirat beérkezett: 2019. 04. 08. 